\title{
ÁNGEL ROSENBLAT Y EL ESPAÑOL DE AMÉRICA: INFLUENCIA DE LA ESCUELA DE FILOLOGÍA ESPAÑOLA EN SU OBRA Y CARTAS A MENÉNDEZ PIDAL
}

POR

\author{
ESTHER HERNÁNDEZ
}

Instituto de la Lengua Española, CSIC

En este artículo mostraremos que la Escuela de Filología Española ejerció una gran influencia en la obra de Ángel Rosenblat desde su periodo de formación. En Buenos Aires tuvo como maestro a Amado Alonso y de alli arranca su interés por el español de América. En Madrid, donde estuvo de 1933 a 1937 bajo la dirección de Américo Castro, se dedicó a la lingüística americana. Participó en la publicación de la revista Tierra Firme durante la Guerra Civil, según hemos sabido por la documentación de los archivos de la JAE. Con la edición de las cartas que Rosenblat envió a Menéndez Pidal, conservadas en la Fundación Ramón Menéndez Pidal, se confirma la relación filológica que siempre mantuvo con el director del Centro de Estudios Históricos y con su escuela.

Palabras Clave: Historia de las ideas lingüisticas, español de América, dialectología, Escuela de Filología Española.

\section{INTRODUCCIÓN}

1. El filólogo americano Ángel Rosenblat, «uno de los mayores conocedores contemporáneos de la dialectología hispanoamericana» ${ }^{1}$, vivió en persona los acontecimientos del Centro de Estudios Históricos [en adelante, CEH] durante los años de la II ${ }^{a}$ República y de la Guerra Civil que van de 1933 a 1937.

Rosenblat perteneció a la escuela de Menéndez Pidal y de Américo Castro ${ }^{2}$, y mantuvo una relación científica profunda y duradera con la corriente filológica

1 LOPE BLANCH, 31 (Filadelfia, 1963): 286.

2 Es comúnmente conocida bajo la denominación de Escuela de Filología Española. Para situarlo en ella, véase la fraternal semblanza que escribió Manuel Alvar sobre Rosenblat, en la que, además del reconocimiento a sus aportaciones científicas, ofrecía interesantes detalles de su personalidad. Alvar, 29 (Caracas, 1973): 67-70. 
española. Su línea de investigación más importante fue el estudio del castellano en América ${ }^{3}$, como él lo llamaba, que le vino dado por su maestro Amado Alon$\mathrm{So}^{4}$, con quien se había formado en Buenos Aires.

La escuela de Menéndez Pidal, como es sabido, logró fructificar en América por medio de Amado Alonso, y a Rosenblat, según sus propias palabras, le cupo «el honor de ser el primer discípulo que tuvo en el Instituto de Filología de Buenos Aires $\rangle^{5}$. De esta manera la escuela madrileña se renovó en la figura de Rosenblat, como miembro hispanoamericano de tercera generación. Los principios metodológicos e intereses de esta escuela ejercieron una enorme influencia sobre su obra, como veremos.

2. Durante su primera estancia en Madrid ${ }^{6}$ Rosenblat fue, además, uno de los primeros miembros de la Sección Hispanoamericana del $\mathrm{CEH}^{7}$, fundada en 1933 y dirigida por Américo Castro, y estuvo comprometido en la publicación de la revista Tierra Firme (1933-1937) ${ }^{8}$. La línea de investigación que cultivó en este

3 Quizá por seguir el criterio de Alonso. Alonso, 1942. Por otro lado, también el filólogo colombiano Rufino José Cuervo, a quien admiraba, lo había denominado así en el primer artículo científico específicamente dedicado al español de América. CUERVo, III [Toulouse, 1901])

4 Según M. A. Morínigo, sucedió que «Amado Alonso, adivinando las apetencias de Rosenblat, lo introdujo en los estudios dialectológicos y lo impulsó a trabajar en una dirección madurada de antemano: la dialectología hispanoamericana, que no tenía cultores por entonces. MorínIGO, XXI/2 [Buenos Aires, 1986]: 6).

5 Rosenblat, 31 (Caracas, 1952): 65.

6 Rosenblat volvió con otra estancia a Madrid en 1971, al edificio de la calle Medinaceli, para terminar su libro sobre el Quijote, que fue publicado por la Editorial Gredos (RoSENBLAT, 1971). Según palabras de Manuel Alvar. AlvAR, 29 [Caracas, 1973]: 68: «a la misma casa -más vieja, con otras caras- que casi cuarenta años antes había frecuentado. No sé si esto es fidelidad: bajo el cobijo del recuerdo de Menéndez Pidal, cerca de los ficheros que ordenaron con Américo Castro». Esta segunda estancia dejó memoria en el centro, porque algunos de los investigadores del ahora Instituto de la Lengua Española nos hicieron saber que «ahí se sentaba Rosenblat», cuando colocamos nuestra mesa de trabajo en ese preciso lugar, cerca de los ficheros.

7 Una de las actividades pioneras del CEH, en los tiempos de la II República, fue la iniciativa de becar a extranjeros que se formaran en la ciencia filológica, de acuerdo con BERNABÉU ALBERT y NARANJo OROVIO (eds.), 2007. Entre los primeros estuvo Rosenblat, quien sin duda cumplió la misión que se había propuesto el centro.

8 La existencia de esta revista (1935-1937) coincidió con los años de la estancia de Rosenblat en el CEH (1933-1937). Véase el interesante estudio en torno a esta revista de BERNABÉU ALBERT y NARANJo OROVIO (eds.), 2007. Por otra parte, en la memoria del centro, bajo el epígrafe «Sección de estudios hispanoamericanos» rezaba lo siguiente: «Esta nueva sección del Centro de Estudios Históricos, constituída en el mes de septiembre de 1933, bajo la dirección de don Américo Castro, prepara los siguientes trabajos: a) Edición crítica de la Verdadera Historia de la conquista de la Nueva España [...]/ b) Bibliografía de las lenguas indígenas de América y Estudios sobre las mismas lenguas, por don Angel Rosenblat y don Lázaro Sánchez Suárez. (Se han ordenado ya unas 10.000 papeletas de la Bibliografía y está casi terminado un estudio sobre dos lenguas de Venezuela) [...]. Memoria, 1935: 248). De esta bibliografía crítica dice Rosenblat: «invertí años y luego se perdió, inconclusa». Rosenblat, 1967: 13. A Manuel Alvar también le debía constar este dato, 
periodo la describía del modo siguiente: «Yo me había entregado, en el Centro de Estudios Históricos, a la lingüística americana» ${ }^{9}$.

Para conocer detalles del tiempo en que estuvo vinculado al CEH, hemos consultado los archivos de la Junta para Ampliación de Estudios e Investigaciones Científicas (en adelante JAE), en el Archivo Virtual de la Edad de Plata ${ }^{10}$. A través de esta documentación ha sido posible recuperar algún detalle para la memoria de este investigador: hemos tenido noticia de sus pasos en el año 1937 por testimonios relacionados con las vicisitudes materiales que en plena contienda afectaron a los filólogos del centro aun siendo, o precisamente por serlo, extranjeros como Rosenblat.

Otro hecho interesante de la biografía de Rosenblat es que conoció personalmente a Ramón Menéndez Pidal mientras éste estuvo exiliado en París, pues durante unos meses lo acompañó en sus quehaceres. De ahí probablemente arranque la intimidad científica y personal que ilustran las cartas que le envió, conservadas en la Fundación Ramón Menéndez Pidal, que editamos aquí ${ }^{11}$.

3. En las páginas siguientes nos proponemos contribuir al examen de los primeros trabajos filológicos hispanoamericanos de Ángel Rosenblat, centrándonos en lo que haga comprender su obra dentro de la escuela filológica madrileña. Queremos poner de relieve la figura de uno de los principales representantes del americanismo en el área de la lingüística española. En este sentido, intentaremos explicar cómo surgió en él el interés por el estudio del español de América y cómo fue su formación en el seno de la escuela de filología española. Desde una visión actual, trataremos de ver la repercusión de su obra en la dialectología y de modo especial en la de Hispanoamérica ${ }^{12}$.

Con ser científicamente importante todo ello, más oportuno creemos que es resaltar aquí que Ángel Rosenblat desempeñó un papel protagonista, silencioso y aún poco conocido en uno de los periodos más interesantes del CEH: cuando los trabajos de esta escuela estaban alcanzando muestras visibles de excelencia científica y se vieron violentamente interrumpidos por la Guerra Civil ${ }^{13}$.

porque apuntaba: «quisiéramos tener tiempo para devolver a don Ángel todos los trabajos que se le han perdido en su peregrinar por el ancho mundo. Alvar, 29 [Caracas, 1973]: 69.

9 Rosenblat, 1967: 13

10 Expresamos aquí nuestro agradecimiento al director del Centro de Documentación, D. Miguel Jiménez, por autorizarnos la utilización de materiales del Archivo Virtual de la Edad de Plata (http://www.archivovirtual.org/).

11 Agradecemos al presidente de la Fundación Ramón Menéndez Pidal D. Diego Catalán que nos haya autorizado la publicación de estas cartas. Igualmente, queremos expresar nuestro agradecimiento a D. José Polo por su amable ayuda y por habernos planteado con generosidad nuevas ideas para continuar esta investigación.

12 Puede partirse de VAQuero XXVI/ 2 (Madrid, 2004): 101-123.

13 Nos referimos a las grandes empresas filológicas, como el Atlas Lingüístico de la Península Ibérica de Navarro Tomás, el Tesoro lexicográfico de Gili Gaya, el Diccionario de la lengua castellana hasta finales del siglo $X V$ de Américo Castro, etc. 
4. Rosenblat dejó escritas unas líneas autobiográficas ${ }^{14}$ en las que «hay una gran lección [...] de un gran filólogo nuestro», según Manuel Alvar ${ }^{15}$. Esta autobiografía encabeza el volumen bibliográfico que preparó su discípula venezolana María Josefina Tejera ${ }^{16}$, donde encontramos reunida la obra de Rosenblat hasta 1967, brevemente comentada y revisada por el autor. Años más tarde la misma autora la completó, con motivo del homenaje que la universidad de Caracas le ofreció por su 70 aniversario ${ }^{17}$.

No falta bibliografía sobre la triple vertiente de su actuación, esto es, de su obra científica, de su labor pedagógica, así como de las labores de difusión de la lengua y la cultura hispanoamericanas que realizón ${ }^{18}$. Y muchas han sido también las reseñas que recibió de las distintas ediciones de sus diversos trabajos en las principales revistas de investigación. No es nuestro propósito enumerar ni glosar su extensa obra, pero interesa subrayar que Rosenblat abordó los temas más importantes sobre el español americano, entre los que se encuentran el de su hipotética fragmentación, su debatido andalucismo, o la procedencia regional y social de los primeros colonizadores. Trató las cuestiones de la unidad, de la norma y de la corrección lingüística con amplitud de criterio. Destacó también por sus investigaciones lexicológicas, que fraguaron en el Diccionario de venezolanismos ${ }^{19}$ y en su exitoso Buenas y malas palabras ${ }^{20}$, de los que habla en las cartas (vid. Anexo, docs. 1 y 8 , respectivamente). También fueron importantes sus estudios sobre la lengua en la Argentina o en Venezuela, así como sus trabajos sobre morfología y fonética dialectal. A él debemos también que fueran valoradas las grandes figuras americanas de la filología hispánica, como Andrés Bello ${ }^{21}$ y Rufino J. Cuervo.

14 Rosenblat, 1967: 11-17.

15 Alvar, 29 (Caracas, 1973): 69.

16 ROSENBLAT, 1967: 11-17.

17 TEJERA, 1974: 543-565. Otros homenajes son los siguientes: Boletín de Lingüística, 12-13 (Caracas, 1997), con motivo de los actos conmemorativos del L Aniversario del Instituto de Filología «Andrés Bello» del 6 al 9 de octubre de 1997; Filología, XXI/ 2 (Buenos Aires, 1986) tras su fallecimiento en 1984; y, por último, dos notas con motivo del centenario de su nacimiento, publicadas por su discípula M. J. Stefano. SteFAnO [Caracas, 2003; 2004].

18 Remitimos al trabajo de PÉREz (Tenerife, 2003): 253-266, quien describe las relaciones interdisciplinares entre historia y lingüística en la obra de Rosenblat y, además, recopila bibliografía sobre las aproximaciones críticas a su obra.

19 Rosenblat trasplantó a Venezuela la idea de hacer un diccionario histórico como el emprendido por Américo Castro en el CEH y utilizaba, incluso, papeletas del mismo tamaño [v. http://www.eud.com/verbigracia/memoria/N236/segunda.shtml, sección fichas Rosenblat redactada por M. J. Tejera], si bien salió como obra póstuma: Diccionario de Venezolanismos, 1983- (v. Anexo, docs. 1, 2).

20 RoSENBlAt, 1956. En este libro reúne más de dos años de artículos periodísticos semanales sobre el español venezolano publicados en el diario de Caracas El Nacional. Compagina en ellos el rigor filológico con la voluntad de divulgación (v. Anexo, docs. 8, 9).

21 El estudio «Las ideas ortográficas de Bello». RosEnBLAT, 1951 es una ejemplar historia de la ortografía castellana. Por las cartas veremos que, en principio, lo había concebido como una obra monográfica; véanse los docs. 2, 3 y 4 del Anexo. 
Por último, conviene subrayar que en muchas de sus reseñas, publicadas sucesivamente en la Revista de Filología Española (en adelante, RFE), Tierra Firme, Revista de Filología Hispánica (RFH) y Nueva Revista de Filología Hispánica $(N R F H)$, se pone de manifiesto el ideario lingüístico e intelectual de Rosenblat. Muestran, además, cuáles fueron sus intereses científicos y hasta su postura emocional hacia las cuestiones del lenguaje, dado que no es raro que ponga en ellas ciertas dosis de pasión o de ironía.

\section{LA «DIÁSPORA»}

5. De las noticias que Rosenblat proporciona de su vida, llama la atención que la primera mitad de ella esté marcada por la diáspora. Primero en sentido literal, porque había nacido en Polonia en 1902 y emigrado a la Argentina junto con sus padres judíos cuando tenía seis años. Con veinticinco, en 1927, conoció a Amado Alonso en el Instituto de Filología de la Universidad de Buenos Aires, encuentro decisivo de su trayectoria profesional y personal.

Después vino el periodo de completar estudios en Europa, donde Rosenblat tropezó con los acontecimientos más graves. En primera instancia, se vio obligado a abandonar la Alemania nazi en la primavera de $1933^{22}$. Años más tarde, en noviembre de 1937, tuvo que abandonar España tras haber colaborado con el bando republicano junto con otros filólogos del CEH. Entonces se dirigió a París, donde tomó contacto con el antropólogo americanista Paul Rivet en el Instituto de Etnografía y con Fouché, en el Instituto de Fonética. Pero de su estancia allí Rosenblat recordaba singularmente «unos seis meses», en los que, según dijo: «Me tocó en suerte trabajar como secretario de don Ramón Menéndez Pidal, a quien acompañaba en sus tareas en la biblioteca de la Sorbona, y en sus paseos por el Luxemburgo» ${ }^{23}$.

De París salió a finales de 1938 y, en su vuelta a América, de nuevo su destino lo llevó a regresar al Instituto de Buenos Aires, en julio de 1939, tras una breve estancia en Ecuador como profesor de Filología, donde a la sazón el gobierno cerró la Universidad de Quito. En el «centro de trabajo intelectual» argentino, según él lo consideraba ${ }^{24}$, permaneció hasta finales de 1946, cuando nuevamente las circunstancias lo hicieron emigrar ${ }^{25}$. Primero lo hizo con los filólogos españo-

\footnotetext{
22 Es un prodigio de diplomacia su alusión a esta beca, que consideró como «un premio que duró muy pocos meses» RosenBLAT, 1967: 12, diciendo sin decir que tuvo que marcharse de Berlín cuando Hitler ascendió a la Cancillería.

23 Rosenblat, 1967: 14

24 RosenBlat, XXXI (Caracas, 1952): 68

25 Deja traslucir sus sentimientos de identificación en la exclamación siguiente: «ioh las eternas desventuras de la emigración!». RosenBLAT, 1965: 255-256.
} 
les, y esta vez lo hará junto con el grupo de filólogos pertenecientes a la escuela de Buenos Aires ${ }^{26}$.

En su recuerdo a Amado Alonso ${ }^{27}$ hallamos unas palabras de aceptación generosa de la diáspora de la filología española, la que casualmente a él, y solo a él, le había tocado vivir por partida doble:

Vivimos una época de dispersión, y la Diáspora es quizá el signo de la cultura. El Centro de Estudios Históricos de Madrid inició en parte la marcha: Américo Castro en Princeton, Navarro Tomás en Nueva York, Sánchez Albornoz en Buenos Aires. El Instituto de Filología de Buenos Aires siguió destino análogo: María Rosa Lida en California, Raimundo Lida en Méjico, Morínigo en La Florida. La dispersión es nueva vida.

Y su nueva vida la encontró en Caracas, donde se estableció ${ }^{28}$, fundó el Instituto de Filología «Andrés Bello» en 1947 (lo dirigió hasta 1977) y fundó otra rama de la escuela de filología española.

6. Si tenemos presente estos intensos años de peregrinaje que caracterizan la primera mitad de su vida ${ }^{29}$, cobran sentido sus palabras cuando le confiesa a Menéndez Pidal que «la política lo perturba todo en nuestros pobres países» (Anexo, doc. 5). No obstante la queja, deja puerta abierta a la esperanza, y en otra misiva (Anexo, doc. 1), donde se evidencia la altura moral de Rosenblat ${ }^{30}$, le comenta al maestro:

[...] espero que la vieja comunidad filológica, que no puede romperse a pesar de todas las catástrofes, dé nuevas pruebas de su existencia. Me gustaría que este nuevo Homenaje fuera una gran obra de concordia ${ }^{31}$.

26 En palabras de Rafael Lapesa: «El triunfo del peronismo hizo imposible la continuidad de esta labor prodigiosa [de la escuela de filología bonaerense]. Amado fue detenido como oponente, y su viaje a los Estados Unidos para recibir un doctorado honoris causa sirvió de pretexto para su destitución de la cátedra y de la dirección del Instituto de Filología». LAPESA, 1996: 21.

27 Rosenblat, XXXI (Caracas, 1952): 70.

28 «Llegué contratado por un año y con la idea de regresar enseguida a la Argentina. Las circunstancias han hecho que constituyera aquí mi hogar, que me hiciera venezolano y que entregara, a los problemas de la lengua y de la educación en Venezuela, todo mi tiempo y todo mi esfuerzo. ROSENBLAT, 1967: 16.

29 Falleció a los 84 años, si bien dice Stefano que «se jubiló en 1976 por motivos de salud, lo cual le impidió la coordinación del Diccionario [de venezolanismos]. STEFANO, 19 [Caracas, 2003]: 88.

30 Son abundantes las valoraciones positivas de la personalidad de Rosenblat y de las muestras de fidelidad por sus maestros. Por ejemplo, Luis Cisneros apuntaba: «pero el bueno de don Ángel con su fresca sonrisa y sus ojillos celestes- se alineaba con Alonso y Henríquez Ureña. CisNEROs, XX/ 1-2 [Lima, 1996]: 90.

31 Se refiere al homenaje que dio lugar a la publicación Estudios dedicados a Menéndez Pidal, Madrid, Patronato Marcelino Menéndez y Pelayo, 1950-1962, 8 vols. 
A pesar de las «catástrofes», lo cierto es que la labor y la producción filológica de Rosenblat fue visible en los dos centros de excelencia de la filología, el CEH y su equivalente hispanoamericano, el Instituto de Filología de Buenos Aires. Y, como es lógico, lo fue de manera evidente en el Instituto de Filología «Andrés Bello» de Caracas, por él creado, desde el que - como acabamos de señalar-, hizo escuela propia y desde donde impulsó los estudios lingüísticos universitarios en Venezuela. Es precisamente esta etapa de su producción la que más se conoce, de ahí que nos vayamos a detener en la etapa de formación, que es en definitiva cuando se forjaron sus ideas lingüísticas.

Con toda claridad y llaneza expresaba su filiación científica en una de las cartas que mandó, en este caso dirigida a Jimena Menéndez Pidal, en la que le pide un artículo para fundar la «Revista de Filología Andrés Bello» ${ }^{32}$ :

Mi Instituto es una prolongación del Instituto de Buenos Aires que dirigía Amado Alonso y del Centro de Estudios Históricos. Me interesa que el artículo de Don Ramón, o la colaboración de Don Ramón, cualquiera que sea, represente el signo de esa filiación. Yo soy filológicamente nieto de Don Ramón, y me amparo en mi abuelo.

En esa misma carta, consciente de su condición migratoria y a propósito de las dificultades para fundar dicha revista ${ }^{33}$, comenta su temor y, al tiempo, su resignada disposición a marchar también de Venezuela - lo que nunca hubo de hacer (salvo para realizar alguna estancia en Argentina, México, España y EE.UU): «El proyecto de publicar la revista tiene ya casi dos años, pero el último tiempo había sido para nosotros muy difícil, y en varias ocasiones creí que tendría que emigrar.» [la cursiva es nuestra].

\section{FORMACIÓN RIGUROSA EN BUENOS AIRES}

7. Por indicación de Menéndez Pidal y enviado por el CEH, Amado Alonso fue contratado por la Facultad de Filosofía y Letras de Buenos Aires para dirigir el Instituto de Filología ${ }^{34}$. Rosenblat formó parte del grupo de alumnos del primer curso que impartió. Lo ha narrado con cierto aire de misterio:

Recuerdo muy bien [...] la llegada de Amado Alonso a Buenos Aires. Me tocó asistir en 1927 a su primer curso de Filología romance [...] Un día por ac-

32 Del mismo modo obró Alonso, quien pretendió relacionar su $R F H$ con la $R F E$, para lo que pidió consejo a Navarro Tomás, entonces en Princeton. GUITARTE, XX/ 1-2, [Lima, 1996]: 73.

33 Fue un periodo especialmente convulso en Venezuela. Para conocer detalles de la sensibilidad social y honestidad con las que actuó Rosenblat en él. FALCÓN DE OvALLES, 12-13 [Caracas, 1997]: 25.

34 MenÉndez PidAL, 17/ 1 (Berkeley, 1963): 5. 
cidente, se apagaron las luces, y discutimos a oscuras el proceso de fraccionamiento de la Romania y la comparación con el desarrollo del español de América. Fue un curso breve pero revelador. Al salir del examen me pidió que me incorporara al Instituto a trabajar con él $[\ldots] .^{35}$

La influencia que ejerció el magisterio de Amado Alonso en él desde entonces, especialmente en la etapa de su «riguroso aprendizaje» ${ }^{36}$ de 1927 a 1930», explica que Rosenblat compartiera la visión y el método científico de la escuela en la que se había formado Alonso. Así pues, de manera indirecta a través de éste, fue como Rosenblat vinculó sus primeras actividades con la escuela de filología española. También de la mano de Alonso le vino el interés por la dialectología hispanoamericana («me puso a trabajar en el castellano de América» ${ }^{37}$ ), tema en el que, como ya hemos comentado, Rosenblat se distingue de manera singular en «nuestra filología» (así la denomina en docs. 1, 3, 6 [vid. Anexo]).

En varias de las cartas que le envía a Pidal habla de su preocupación por la salud de Amado Alonso, a quien considera «su padre», y también le confiesa: «la muerte de Alonso ha sido para mí un golpe muy duro» (Anexo, docs. 2-5) . Y en la nota que escribió con motivo de su fallecimiento llegó a decir que «su obra [la de Amado Alonso] es lo que él escribió, y también en gran parte lo que escribieron sus discípulos y amigos» ${ }^{38}$. Sin duda, con su elegancia habitual, se estaba refiriendo a sí mismo.

8. En rigor, la obra de Rosenblat está planteada con una visión científica conjunta de la historia, la lingüística y la crítica literaria. En una reseña a la obra de Iorgu Iordan, que fue después reelaborada y publicada en español por Manuel Alvar ${ }^{39}$, Rosenblat afirmaba: «la filología española, presidida desde la época de los neogramáticos hasta hoy por la figura de Menéndez Pidal, mantuvo desde sus primeros días la conexión entre lengua y literatura, entre historia de la lengua e historia, y ha ido acogiendo, con un sentido progresivo y renovador, los intereses nuevos. Ni la geografía dialectal ni los estudios estilísticos han sido en España materia de heterodoxia» ${ }^{40}$. En la misma dirección, apostillaba Eugenio Coseriu: «La escuela de Menéndez Pidal [...] mantiene firme $[\ldots]$ el principio de unidad de las ciencias filológicas, [...] por eso los lingüistas españoles suelen conciliar la erudición con la agudeza y, ya por su formación, son al mismo tiempo historiadores y críticos literarios» ${ }^{41}$.

35 Rosenblat, 1967: 65.

36 En el tomo II de la Biblioteca de Dialectología Hispanoamericana (en adelante BDH), A. Alonso afirmaba lo siguiente: «el tomo I de esta obra lo preparamos Ángel Rosenblat y yo. Para Ángel Rosenblat, formado a mi lado en este Instituto, aquel trabajo fué un riguroso aprendizaje, de modo que la elaboración del tomo II se le pudo encomendar íntegramente» (p.VI).

37 RosenBlat, 31 (Caracas, 1952): 61

38 Rosenblat, 31 (Caracas, 1952): 61

39 IORDAN, Iorgu, y MANOLIU, María, 1972.

40 Rosenblat, II (Buenos Aires, 1940): 182-183.

41 COSERIU, 1977: 253. 
A este respecto, no es ocioso señalar la agudeza del estilo de Rosenblat: lo bien que escribía ya fueran reseñas, ediciones críticas, concienzudos trabajos científicos de dialectología o de lexicología histórica, o ya fueran los trabajos de divulgación sobre diversos aspectos de la lengua que escribía para la prensa ${ }^{42}$. En verdad, resulta peculiar en este filólogo la precisión y finura estilística de sus trabajos, del mismo modo que las hallamos singularmente en otros autores de la escuela como Dámaso Alonso o Rafael Lapesa, por ejemplo. Quienes conocieron a Rosenblat destacan cómo volvía sobre sus obras, las corregía, las reelaboraba ${ }^{43}$; lo cual a la vista está, porque Rosenblat tenía un estilo claro y con gran sentido pedagógico. Ciertamente poseía originalidad personal en su modo de escribir: lo hacía literariamente, con humor inteligente ${ }^{44}$, con una especial nostalgia. Para la presentación de sus obras completas ${ }^{45}$, se ha utilizado una frase del propio autor, que ilustra su concepción del lenguaje: «creo que el deber revolucionario del escritor es escribir bien. Ese es mi compromiso».

Sus publicaciones muestran que cultivó las áreas de la historia, la lingüística y la crítica literaria como otros miembros de la escuela (el mismo Pidal, Castro, los Alonso, Alvar, etc.), actividad científica que hoy calificaríamos de interdisciplinaria. Así, en sus publicaciones de lingüística, podemos encontrar meticulosos análisis en los niveles fonético, morfológico y léxico, explicados no sólo formalmente, sino en su contexto histórico y cultural. Rosenblat, con Alonso, consideraban que «no hay nada mecánico en la lengua», y que «el espíritu preside toda la evolución» (BDH, t.I: 445, n.1). En efecto, le interesaba el genio de la lengua, y se acogía al idealismo lingüístico de Vossler, que tiende a ver las conexiones íntimas entre los fenómenos lingüísticos y los culturales, amparado en última

42 Rosenblat fue pionero en este género (hoy muy apreciado por servir para acercar los avances científicos a la sociedad), que desarrolló por vez primera en su corta estancia en Ecuador en 1939 (en el periódico El Comercio), en Buenos Aires (La Nación) y ya de manera continuada en Caracas (El Nacional).

43 Así lo ha expresado Josefina de Stefano: «porque una característica del profesor Rosenblat era que nunca abandonaba sus trabajos. Nacían como cortos artículos y al paso de los años iban creciendo hasta convertirse en extensos trabajos; volvía a ellos para perfeccionarlos y corregirlos, agregando siempre nuevos datos y nuevos testimonios. Todo ello es prueba de su incansable espíritu de trabajo y honestidad profesional así como de fidelidad a sus intereses. STEFANO, LXIV/ 328 [Caracas, 2004]: on line). Otra de sus discípulas decía que Rosenblat retomaba sus obras «para agregar datos y hasta para rehacerlas como era su expresión. TEJERA, 12-13 [Caracas, 1997]: 185.

44 Hay muestras en toda su obra, pero es francamente recomendable la lectura de los episodios del «turista» en ROSENBLAT, 1971.

45 Luciana de Stefano ha escrito que: «en 1983 se inició al proyecto editorial de Monte Ávila para publicar la Biblioteca Angel Rosenblat, que debía reunir en diez tomos sus escritos. Era un proyecto de suma importancia, ya que de ese modo se recopilaría en una sola colección todos sus trabajos, que hoy en día están dispersos y son de difícil acceso, pero muy a nuestro pesar solamente llegaron a publicarse los seis primeros volúmenes. STEFANO, 19 (Caracas, 2003): 90. Por su parte, Josefina Tejera hizo una reseña de los volúmenes publicados, y también aportaba noticias de la colección, véase TEJERA 12-13 (Caracas, 1997). 
instancia en el concepto de forma interior del lenguaje de Wilhelm von Humboldt. Rosenblat se cuestionaba en una de sus primeras reseñas «¿qué otra finalidad sino esta, - la de penetrar en el alma de un pueblo y, por tanto, en la del hombre - pueden tener las investigaciones filológicas?». ${ }^{46}$

Rosenblat hizo varias ediciones de textos ${ }^{47}$, entre la que destaca la edición de los Comentarios reales de los Incas, de la que José Luis Rivarola sigue valorando el rigor de sus criterios ${ }^{48}$. También hizo ediciones de Sarmiento de Gamboa, de las cartas de Lope de Vega y de los «capítulos» que se le olvidaron a Cervantes (v. Anexo, doc. 1), así como del Amadís. Asimismo realizó interesantes análisis, por ejemplo sobre la lengua de Ortega y Gasset, y sobresale su análisis de la lengua del Quijote ${ }^{49}$, tema favorito de la Escuela de Filología Española ${ }^{50}$. Este estudio se volvió a editar con motivo del IV Centenario en 2005, lo que muestra la actualidad de sus planteamientos. Sería prolijo enumerar sus contribuciones en este sentido, pero interesa destacar ahora que en todas ellas se compagina lo literario, lo lingüístico y lo histórico. En este último sentido, se antoja también la posible influencia de Américo Castro, a quien dedicó el libro del Quijote.

9. En cuanto al método científico, desde los comienzos, con su colaboración en la $B D H$, la actividad de Rosenblat se desarrolló con el más estricto rigor y severidad científica, lo que emparenta su producción con la obra pidalina. Manuel Alvar manifestó su admiración por las Notas de morfología dialectal: «¿dónde se aprenderá tanto?»—-se preguntaba ${ }^{51}$. También lo hizo M. A. Morínigo, quien aseguraba, con toda razón, que «constituyen por sí solas un manual de dialectología hispanoamericana» ${ }^{52}$. Ciertamente, la reelaboración del II tomo de la $B D H$, que comprende la parte de la morfología, constituye una de las aportaciones más importantes de Rosenblat a la ciencia lingüística ${ }^{53}$. Por el mismo tiempo elaboró su tesis doctoral, sobre Morfología del género en español, que nunca llegó a publicar, pero de la que por indicación de Alonso fue sacando a la luz capítulos en las revistas científicas ${ }^{54}$; uno de ellos lo envío para el homenaje a Pidal, como podemos leer en una de las cartas (vid. Anexo, doc. 1).

46 Rosenblat, XX (Madrid, 1933): 407.

47 Se estrenó con el Reloj de príncipes..., Madrid, 1936. Vale la pena recordar que una de las misiones del CEH fue la edición de textos, de ahí seguramente que Rosenblat se dedicara a este quehacer filológico.

48 Véase VEGA, GARCILASO de la «El Inca», 2002 [1609].

49 Véase la reseña de SÁNCHEZ, 11 (Madrid, 1972): 177

50 Véase Jauralde Pou, XVI/1-2 (Madrid, 2005): 3-14.

51 Alvar, 29 (Caracas, 1973): 67.

52 MorínIGO, XXI/ 2 (Buenos Aires, 1986): 7.

53 La obra fue objeto de reseña por parte de GILI GAYA, XXX (Madrid, 1946): 176-177; NAVARRO TomÁs, $39 / 4$ (New York, 1948: Dec): 340-341; MEIER, 63/1-2 (Frankfurt am Main, 1951): 424-427.

54 Los artículos sobre morfología que publicó fueron: RosenBlat, VII (México, 1953) 95112; V/1-2 (Buenos Aires, 1959): 35-46; XVI (México, 1962): 31-80. 
10. Con el estudio del español de América como misión fundamental de su producción científica, Rosenblat cumplió uno de los objetivos que se había propuesto su maestro Amado Alonso: el de fomentar la investigación dialectológica en América ${ }^{55}$. Y es que Alonso, al llegar a América, descubrió un campo, el de la dialectología hispanoamericana, en el que todo estaba por hacer. El dedicarse a esta tarea lo justificaba por que «los filólogos han prescindido hasta ahora de América, que es tanto como renunciar a más del $80 \%$ de la geografía románica» $(B D H$, I: 5).

Por otro lado, el panorama de las investigaciones en España sobre el español de América era poco fértil a principios del siglo XX. El órgano por excelencia de la escuela de filología, la $R F E$, no le prestó atención al español americano ${ }^{56}$ hasta la publicación de los trabajos de Pedro Henríquez Ureña ${ }^{57}$, que entonces disfrutaba de una estancia en el CEH ${ }^{58}$.

Sin entrar aquí en el desarrollo de los estudios sobre el español de América en la filología hispánica, ni en la historia de las ideas lingüísticas sobre tal concepto, sí conviene señalar que a Amado Alonso, desde su emplazamiento bonaerense, se debe en gran medida el impulso de los estudios sobre el español americano y, lo que más interesa aquí, que Rosenblat lo encarnó por ser su primer discípulo. Prueba de ello es que «la inmensa mayoría de los trabajos escritos por Ángel Rosenblat a lo largo de su fecunda vida está dedicada al español de América» ${ }^{59}$

Asimismo, Alonso había establecido el principio metodológico de que el español de América ha de estudiarse dentro del cuadro de la dialectología española y de todo el español de España, antiguo y moderno, literario y corriente, común y dialectal, general y regional ${ }^{60}$. Este principio lo siguió Rosenblat al pie de la letra en su obra ${ }^{61}$

55 Véase el estudio en torno al tema del español de América en la obra de Alonso: MARTínEZ MARÍN, Juan, 15 (Alicante, 2001): 177-186.

56 Acaso porque pronto aparecieron revistas que se encargaron específicamente de los problemas de la lengua en América, como los Cuadernos del Instituto de Filología de Buenos Aires (1925) continuados en Filología, o la RFH (1939) reconvertida, a su vez, en la $N R F H$ (1947), lo cierto es que la $R F E$ no ha sido foro de especial resonancia de la materia. Para Antonio Quilis, la $R F E$ «no ha publicado muchos estudios sobre el español de América, pero, comparándolos con el total de artículos que fue viendo la luz en cada época, su aportación es importante tanto por su número como por su contenido. GARCía MouTON, 2003: 7). Por otra parte, A. Quilis cometió un ligerísimo error en la interpretación de las siglas de dos reseñas de la $R F E$, que atribuyó a «A[ngel] $\mathrm{R}$ [osenblat]» (ibid: 8, 10), cuando debieron ser compuestas por Alfonso Reyes.

57 Véanse los artículos sobre la polémica del andalucismo de HenRíQuez UREÑA, VII (Madrid, 1921): 357-390. Wagner, XIV (Madrid, 1927): 20-32. Henríquez UreÑa, XVII (Madrid, 1930): 277-284. XVIII (Madrid, 1931): 120-148.

58 La presencia de hispanoamericanos en el CEH «fue mínima: entre 1915 y 1923 permaneció en el centro el mexicano Alfonso Reyes y entre 1918 y 1922 investigó el dominicano Pedro Henríquez Ureña, ambos en la sección de Filología». BERnABÉu Albert y NARANJo Orovio (eds.), 2007.

59 LOPE BLANCH, 1990: ix.

60 Coseriu, 1977: 258

61 Con la enorme ventaja de que habiendo vivido en varios lugares conocía bien diversas variedades del español (bonaerense, madrileña, de Quito y venezolanas). Esta visión múltiple, sin 
y, desde nuestra visión actual de la dialectología y de la historia de la lengua española, sigue estando vigente, solo que ahora se dispone de una mayor base documental y, sobre todo, de fuentes no necesariamente literarias. Sin duda, para el tema de la formación de las distintas variedades americanas y, de manera específica, si se quiere saber en qué momento sucede la «nivelación» lingüística (en terminología de Alonso), es necesario conocer bien la historia de los distintos dialectos peninsulares. Lo ha demostrado con solvencia en nuestros días Juan Antonio Frago, cuando trata los factores de lo que él denomina «criollización» lingüística ${ }^{62}$.

Finalmente, también debió de actuar en la orientación americanista de Rosenblat la presencia de Pedro Henríquez Ureña en el Instituto de Filología de Buenos Aires. El propio Rosenblat lo confesaba: «Don Pedro nos comunicó a todos su fervor americano» ${ }^{63}$. Lope Blanch ha hablado de «la firme lealtad de Rosenblat para con sus maestros y, en especial, para con Henríquez Ureña, cuya obra, cuyas ideas están siempre presentes en los escritos de don Ángel» ${ }^{64}$. En efecto, Rosenblat no se pronunció abiertamente en contra de la teoría sustratista o del andalucismo del español americano, pese a los avances científicos ${ }^{65}$.

\section{«TRABAJÉ CON ALONSO DÍA A DÍA»}

11. En los tres años de formación en Buenos Aires, de 1927 a 1930, Rosenblat se empleó a fondo en la traducción y reelaboración del trabajo de Espinosa ${ }^{66}$, en el que colaboró con Alonso «día a día».

Los estudios de Aurelio Macedonio Espinosa «señalaron época en nuestra Dialectología: ningún dialecto hispánico había sido inventariado con más minuciosa exactitud ni tan ampliamente relacionado con las formas correspondientes de América y de España», había asegurado S. Gili Gaya ${ }^{67}$. En este sentido, desde nuestra perspectiva actual, resulta singular el hecho de que, de todos los dialectos de nuestra lengua, peninsulares y extrapeninsulares, fuera el novomexicano de los primeros en ser objeto de análisis científico con tanto detalle ${ }^{68}$.

duda, permite identificar con mayor facilidad las similitudes y las discrepancias lingüísticas entre los distintos dialectos.

62 Véanse Frago Gracia, 1999; id., XXXVII (Santiago de Chile, 1998-1999): 523-539.

63 Rosenblat, 31 (Caracas, 1952): 69.

64 LOPE BLANCH, 1990: XI.

65 Juan Antonio Frago ha afirmado que «también suele aceptarse la opinión mantenida por Á. Rosenblat, en el sentido de que todos los rasgos caracterizadores del español americano -yo lo limitaría a muchos de ellos- tienen su origen en España. Y, sin embargo, ni Rosenblat ni Alonso fueron precisamente entusiastas difusores de la postura andalucista, sino más bien al contrario». FraGo GRACIA, 1999: 309.

66 ESPINOSA, 1911.

67 GILI GAYA, XXX (Madrid, 1946): 176.

68 Acaso se justifique por ser dialecto de frontera, en donde se hace más necesaria la identidad, puesto que no hacía mucho (1848) que se había perdido aquella antigua provincia de México. 
Como es natural, en la edición de Alonso y Rosenblat de $1930^{69}$ resulta difícil conocer cuál pudo ser la aportación del discípulo y cuál la del maestro. En cualquier caso, los Estudios contienen información científica valiosa añadida al texto, basada en las abundantes aportaciones bibliográficas que incorporaron; de hecho, duplicaron con creces la bibliografía que Espinosa había utilizado en 1908: de 149 referencias a $327^{70}$. En la mayoría de los casos las notas son ampliaciones a las explicaciones de Espinosa o sumas de ejemplos. Alonso y Rosenblat comentaban:

nuestra labor más dura consiste en relacionar geográficamente cada forma dialectal con la correspondiente de todas las regiones hispánicas: para ello hemos necesitado rebuscar no sólo en los estudios dialectales donde se las ordena metódicamente, sino en el mar de papel de los numerosos vocabularios regionales y en los libros de carácter gramatical y didáctico $(B D H, \mathrm{I}: 6)$.

En efecto, la variación fonética de los distintos dialectos peninsulares y también de los hispanoamericanos está profusamente documentada. Sus fuentes son sobre todo vocabularios dialectales, porque en esta época no se disponía de materiales textuales que recogieran muestras de lenguaje no literario o geolectal ${ }^{71}$. No había tampoco una separación tan clara como la hay hoy entre la dialectología y la historia de la lengua, pues estaba plenamente vigente el principio que había establecido Saussure de que ambas disciplinas eran inescindibles.

En el primer tomo de la $B D H$ contemplamos la actividad de Rosenblat en el momento inicial, y en ella se pone de manifiesto la íntima unidad de la lingüística hispanoamericana con la española, como no podía ser de otro modo. Asimismo, esta edición conjunta de Rosenblat y Alonso es una de las primeras publicaciones de un dialecto castellano con textos en transcripción ortográfica y fonética siguiendo las normas de la $R F E$, pulcramente editados a dos columnas ${ }^{72}$.

Volviendo a los trabajos de Rosenblat en el instituto de Buenos Aires, sabemos que no debió ser este el único cometido del discípulo, pues en un informe del director Amado Alonso, con fecha 14-2-1929, se refieren las actividades del año 1928 y figura que «el empleado temporero de este Instituto S. Rosenblat ha

69 EsPinOsA, 1930.

70 Formaba parte del estilo de esa época este tipo de reelaboraciones, como la que hizo Américo Castro de la obra de Meyer-Lübke, en la que debió inspirarse Alonso. GUITARTE XX/ 1-2, [Lima, 1996]: 68.

71 El gran proyecto emprendido por Manuel Alvar y Antonio Quilis, el Atlas de Hispanoamérica, tenía como objetivo aportar materiales para el conocimiento de la dialectología hispanoamericana. Alvar y QuiLIS, 1984. Por otro lado, desde el punto de vista de la historia de la lengua, la elaboración de corpus documentales, como el CORDE (www.rae.es), ha venido a desempeñar esa función. En el caso específico de la lengua en Hispanoamérica, contamos con el corpus de P. BoydBowman con textos no literarios, cuando menos en el nivel léxico. BoYD-BowMAN, 2003.

72 Sigue la misma tradición de edición de textos, entre otras, la publicación de ALVAR et al, 1995. 
estado reuniendo materiales para la confección del tomo referente al judeoespañol» $\rangle^{73}$. Vemos, pues, al joven Rosenblat desempeñando una labor de recopilación bibliográfica; y no será la única tarea de este tipo que tuvo que realizar, porque también se encargó de llevar a cabo una recopilación bibliográfica sobre las lenguas indígenas americanas en Madrid, como ya hemos anotado.

\section{DOS AÑOS Y MEDIO EN LA UNIVERSIDAD DE BERLÍN}

12. Rosenblat ganó una beca para completar estudios en Alemania, país que estaba entonces a la cabeza de la ciencia y de la técnica mundiales, y al que habían acudido a formarse otros miembros del CEH (como Américo Castro, Navarro Tomás o Amado Alonso).

En febrero de 1933 Rosenblat dio una conferencia en el Romanistische Seminar de la Universidad de Berlín, que constituye su primera publicación con autoría única, que tituló Lengua y cultura en Hispanoamérica. Tendencias actuales, y de la que hizo varias ediciones. Marcel Bataillon escribió el prólogo de la tercera, de 1951, y decía: «L'opuscule de Rosenblat figura alors pendant plusieurs années parmi les livres recommandés aux hispanisants parisiens, comme étant la plus maniable, la plus attrayante, la plus intelligente initiation à l'espagnol d'Amérique» ${ }^{74}$.

Resulta ejemplar la fidelidad de Rosenblat a sus trabajos, desde este primer trabajo de juventud (tenía treinta años), donde aborda temas que serán recurrentes en toda su obra: la «resonante» polémica de Cuervo y Varela sobre la fragmentación del español en América, su formación y evolución. Su idea fundamental, que mantuvo a lo largo de toda su carrera científica, es que existe una tendencia de la lengua a la unidad por la vía del castellano culto, tanto en España como en América.

En una de las cartas a Pidal, vemos cómo le elogia al maestro su modo ejemplar de elaboración científica, que él también practica, y le dice: «estoy asombrado de cómo puede usted remozar día a día sus viejos temas» (v. Anexo, doc. 2).

\section{EN EL CENTRO DE ESTUdios HistóRICOS}

13. En 1933, al poco tiempo de llegar a Madrid, publicó sendas reseñas para el tomo $\mathrm{XX}$ de la $R F E$. En ellas, fuera del rigor y del lenguaje científico, apreciamos rasgos de la ideología y de la visión de la lengua española de Rosenblat. En la primera se hacen patentes sus ideas en torno al carácter descriptivo y no prescriptivo que han de tener los estudios filológicos, y mucho más los dialecta-

\footnotetext{
73 Guitarte, XX/2 (Lima, 1996): 74.

74 Rosenblat, 1933; 1949; 1951; 1960; 1962.
} 
les. Es una reseña crítica durísima, en la que dice, por ejemplo, que «el libro del Sr. T. no es utilizable ni siquiera por los materiales $\rangle^{75}$. Sin duda, esta obra fue mal recibida por la escuela (Alonso también la reseñó en 1941), entre otras razones porque estaba en franca oposición con sus esfuerzos por introducir la investigación científica en torno a la lengua de Argentina, según asegura G. Guitarte ${ }^{76}$.

El joven Rosenblat hizo varias reseñas más para la $R F E$ y para Tierra Firme, en las que destila su fino humor. Así, en una las de Tierra Firme sentencia «el trabajo de Max Daireaux [...] es más propio de un periódico de derechas de Francia [...] En una Iniciación a la vida argentina hay que tener la discreción de relegar a un segundo plano los desahogos íntimos ${ }^{77}$. Sin duda, algunas cuestiones parece que le afectaban más. Por ejemplo, en otra reseña para la $R F E$ leemos: «El Sr. Mézan es un sefardita de Sofía que conserva el culto de la tradición judeo-española [...] Su tesis no es más que una manifestación pueril de racismo científico» ${ }^{78}$.

En nuestra opinión, de entre las que escribió en el CEH sobresale la que hizo a la obra de Cuervo ${ }^{79}$ (autor que inspiró a Rosenblat en su producción científica), pues en ella resulta absolutamente esclarecedora su visión del problema de la lengua en América. Vale la pena reproducir algún fragmento, revelador ya en este periodo formativo en el CEH de su ideal de una cultura supranacional, con tendencia a la universalidad.

¿Conducen las leyes de la naturaleza sin remedio, inexorablemente, a la disgregación lingüística de las comunidades humanas? [...] Ya no puede hablarse de aislamiento hispanoamericano en relación con España, y la influencia expansiva de las distintas capitales es función en gran parte de una nueva norma, basada en aspiraciones de cultura superior [...] La vida intelectual y social y hasta el movimiento político se desenvuelven hoy por cauces paralelos o comunes, con repercusiones instantáneas, en todos los países de habla hispánica. Por otra parte, se percibe en todos los países una mayor influencia de los instrumentos de la cultura (escuela, literatura, prensa, cinematógrafo). [...] Junto a esa comunidad de norma, las relaciones recíprocas y la elaboración colectiva de la cultura constituyen la garantía de una evolución pa-

75 Rosenblat, XX (Madrid, 1933): 297-300.

76 Guitarte, XX/ 1-2, (Lima, 1996): 70.

77 RosenBlat, II/3-4, (Madrid, 1936): 566.

78 Rosenblat, XXIII (Madrid, 1936): 423.

79 Reconocemos la pluma de Rosenblat en el ejemplar de la Biblioteca del Centro de Humanidades, donde con cuidado esmero corrigió algunas erratas; de hecho, en la reseña hablaba del «descuido lamentable de este volumen. Rosenblat, II/2, [Madrid, 1936]: 325. Por otro lado, en esta reseña, Rosenblat apuntaba: «el pedagogo bogotano fué pasando, con las seis ediciones de sus Apuntaciones, con su Diccionario de construcción y régimen, con sus Notas a la Gramática de Bello y con tantos otros trabajos, a ser un filólogo moderno, el creador de la dialectología hispanoamericana, mucho antes de que apareciesen los trabajos de Lenz y de Espinosa y cuando no existía aún la Revista de Filología Española ni podía hablarse de una escuela de Menéndez Pidal» (ibid). 
ralela. Desde luego, con todas las modalidades estilísticas del genio personal, local o regional. En este sentido se podrá decir, sin preeminencias ni resentimientos, que los españoles e hispanoamericanos son por igual los dueños de la lengua común.

14. Finalmente, Rosenblat escribió: «de mi época de Madrid quedan dos trabajos extensos, publicados en Tierra Firme, la revista que fundó Américo Castro y que fue en parte el órgano de nuestra Sección Hispanoamericana» ${ }^{80}$. El primero fue el titulado El desarrollo de la población indígena de América desde 1492, luego reelaborado, ampliado y convertido en La población indígena y el mestizaje en América (v. Anexo, docs. 4 y 5). En efecto, este trabajo lo fue desarrollando a lo largo de varias redacciones, desde 1935 hasta su última versión de $1964^{81}$. De él decía que era «quizá el más conocido y citado de mis trabajos. Quizá el más discutido, y discutible. En él me propuse una tarea que entonces parecía temeraria, y lo es todavía hoy: calcular la población que había en América en la época del Descubrimiento» ${ }^{82}$.

Sin duda, la tarea podría resultar temeraria, pero alguien tenía que empezar a tratar la cuestión, si bien él mismo confesaba un poco más adelante que: «aspiraba sólo a señalar un camino para investigaciones más completas». El sesgo histórico es patente en esta publicación y los conceptos de población, influencia y mestizaje son inherentes al estudio de la lengua en América por ser parte fundamental de las características que la definen. En definitiva, Rosenblat no separó el estudio y el análisis de los fenómenos lingüísticos o literarios de la historia y de las circunstancias sociales ${ }^{83}$.

En cuanto a la segunda publicación de Tierra Firme ${ }^{84}$, su trabajo sobre las lenguas de los otomacos y taparitas es una reconstrucción etnográfica basada en las noticias de los cronistas misioneros y viajeros ${ }^{85}$. En la segunda parte, con la ayuda de dos vocabularios inéditos de la Biblioteca de Palacio de Madrid, hace un análisis comparativo de la lengua de ambas etnias, haciendo referencia a misioneros y conquistadores que las conocieron de cerca. De este trabajo, Rosenblat escribió: «el estudio de la lengua me llevó a la reconstrucción cultural — la relación entre la palabra y la cosa-, y caí así en el vasto y seductor campo de la etnología. Al estudiar los otomacos y taparitas, no podía sospechar que el destino me iba a convertir, por vías inescrutables, en compatriota de esos indios» ${ }^{86}$

80 Rosenblat, 1967: 13.

81 Rosenblat, I (Madrid, 1935): 115-127; 1/2: 117-148; I/3: 109-141; 1945; 1954.

82 ROSENBLAT, 1967: 11-17.

83 V. LERNER.

84 Rosenblat, II [Madrid, 1936). Asimismo, lo presentó en el XXVI Congreso de Americanistas en Sevilla, del 12 al 20 de octubre de 1935.

85 Véase, por otro lado, el interesante estudio sobre la influencia de los misioneros en la difusión del español: GonZÁlez OLLÉ, XII-XIII (Valladolid, 1996-1997): 327-360.

86 ROSENBLAT, 1967: 14. 


\section{LOS DOCUMENTOS DEL ARCHIVO DE LA JUNTA AMPLIACIÓN DE ESTUDIOS}

15. Hemos visto hasta ahora las actividades de Rosenblat en su periodo de formación, ligado a la escuela fundada por Menéndez Pidal. A continuación, vamos a tratar de mostrar que Rosenblat, una vez que estalló la guerra, participó también en las actividades del Centro de Estudios Históricos como un miembro más del mismo.

El archivo de la JAE, sección Secretaria, serie Correspondencia General conserva una serie de cartas del año 1937, en las que Ángel Rosenblat aparece como colaborador del CEH y como encargado de la publicación de Tierra Firme. A través de estos documentos podemos conocer su intervención en la guerra (en febrero está en Madrid, en octubre ya en Valencia) y dan testimonio de que participó en el frente republicano.

El primer documento es una carta mecanografiada de Rafael Lapesa, desde el $\mathrm{CEH}$, dirigida a Tomás Navarro Tomás, en Valencia, con fecha de 3 de febrero de 1937. En ella, Lapesa le informa de la situación de algunas personas respecto a la guerra: «Rosenblat y Ramón Iglesia están prestando servicio de guerra, como intérpretes, uno con la Brigada Internacional, y otro en la Columna Prada». A continuación, de la propia mano de Lapesa, aparece anotado: «Ramón Iglesia es teniente ayudante del comandante de Pablo y Rosenblat acaba de volver y seguramente se reintegrará a la oficina de Prensa del Ministerio de Estado, que es también servicio de guerra» ${ }^{87}$.

No es de extrañar que Rosenblat participara en la guerra como intérprete. Constan sus conocimientos de inglés, francés y alemán (por la traducción de Espinosa, por sus reseñas de libros en esas lenguas para RFE y Tierra Firme, así como por su lectorado en Berlín), pero acaso más eficaz resultase que su lengua materna fuera una lengua germánica, el yidish. Así, el testimonio de Lapesa parece indicar que Rosenblat participó en la batalla de Madrid como intérprete de las Brigadas Internacionales, compuestas, como se sabe, por soldados voluntarios extranjeros de la izquierda política. Y lo hizo cuando más se necesitaba, porque el pico del reclutamiento brigadista tuvo lugar precisamente en la primavera de $1937^{88}$. Los voluntarios procedían de todo el mundo, pero la mayoría tenían orígenes europeos, como el propio Rosenblat. Según Graham, «en realidad, es imposible comprender las Brigadas Internacionales como un fenómeno histórico sin tomar en cuenta sus orígenes en la diáspora europea ${ }^{89}$. Pero además, entre los brigadistas había muchos voluntarios judíos, cerca de un cuarto del total ${ }^{90}$. En

87 Archivo de la Residencia de Estudiantes, signatura JAE 280790340/JAE/167/44/4.

88 Véase GRAHAM, 2006: 63.

89 GRAHAM, 2006: 64

90 Sería interesante rastrear su posible intervención entre los judíos polacos como él. Porque, según Graham, hubo una gran proporción de judíos entre los brigadistas polacos, lo que «propició que se formara una compañía judía específica dentro de su batallón, que atrajo a muchos volunta- 
suma, en él confluían varios factores para prestar ayuda al bando antifascista: posiblemente su ideología, haber sido hijo de la emigración europea de principios del siglo XX y ser de origen judío.

Tres meses más tarde, Lapesa vuelve a escribir a Navarro Tomás, el 3 de mayo de 1937. En esta carta, Lapesa le refiere el estado de los trabajos del CEH. Es un informe en el que le va dando cuenta de varios asuntos ${ }^{91}$, y uno de ellos es la revista Tierra Firme. Lapesa dice: «He enviado a Rosenblat lo que pedía con más urgencia, por medio del Sr. Sánchez Arcas». Vemos, pues, que Rosenblat cumplió una misión muy importante en la publicación de esta revista en plena guerra. También, pocos días después, en una carta de 15 de mayo de 1937, en la que Lapesa le informa a Navarro Tomás de otros asuntos, comprobamos que Rosenblat asumió la responsabilidad de la publicación de Tierra Firme, pues insiste en la misma idea: «los libros están preparados, y con ellos irán los materiales que me pidió Rosenblat para Tierra Firme»».

En otro interesante documento, el Secretario del CEH Tomás Navarro Tomás escribe y rubrica desde Valencia un oficio con fecha 23 de julio de 1937, dirigido al Ministro de Trabajo y Asistencia Social. Hace constar en él la vinculación oficial de Rosenblat como colaborador del CEH con objeto de obtener las «cartas de identidad profesional», así como «su lealtad»a la República ${ }^{92}$.

El 6 de agosto de 1937 Navarro Tomás ${ }^{93}$ le escribe otra carta a Lapesa, informándole de algunos pormenores de la $R F E$. En ella expresa el espíritu de la JAE y apunta que «los compañeros de la Junta son todos de la opinión que las publicaciones se activen para dar testimonios de la labor con la frecuencia posible». Por lo que respecta a Tierra Firme, asegura que ya hay varios pliegos tirados. Le pide que busque en Madrid documentación de Rosenblat para que pueda seguir teniendo los papeles en regla ${ }^{94}$. Aparece Rosenblat aquí de nuevo relacionado con la edición de pliegos de esa revista.

rios internacionales [...] Sin embargo, la mayoría de los brigadistas judíos en España lucharían en otras unidades y muchos consideraban su antifascismo una seña de identidad más importante que el hecho de ser judíos. Al combatir el fascismo en España, todos los brigadistas estaban resistiéndose a la vez a muchas formas de exclusión social y política violentas». GRAHAM, 2006: 65.

91 Entre ellos figuran: «notas de trabajo, índice de la revista [de la $R F E$ ], bibliografía sobre los gitanos, imprenta de Hernando, material de la revista, Tierra Firme, disco de Cajal, locales del Centro, libros pedidos por Vallelado, peticiones de libros». Resulta conmovedor el apartado de locales del Centro, donde le explica que han prestado unos locales de la primera planta de Medinaceli para almacén de víveres del Hospital militar alojado en el Hotel Palace (Archivo de la Residencia de Estudiantes, signatura JAE 280790340/JAE/167/44/22).

92 Residencia de Estudiantes, signatura JAE 280790340/JAE/168/16/31.

93 El Archivo virtual de la Edad de Plata la registra como anónima, pero es evidente la autoría de Navarro por semejanza formal con otras cartas y por su estilo.

94 «También le agradeceré diga a Felipe que mire en las nóminas la fecha en que comenzaron a trabajar en el Centro los Sres. Bonfante y Rosenblat. Si no tuviese él los datos, que vean el fichero de la Secretaría de la Junta o los cuadros que Celestino tiene en los armarios metálicos de la Junta y que Tomás puede darle. Se necesitan con alguna urgencia para que puedan despacharles en la Dirección Provincial del Trabajo las nuevas cartas», (Archivo de la Residencia de Estudiantes, signatura JAE 280790340/JAE/167/44/49). 
El 14 de octubre de 1937 Navarro Tomás le escribe a Homero Serís y le cuenta el estado de las actividades del Centro, ya desplazado de Madrid. Navarro hace por transmitir una imagen de normalidad científica y cultural, y asegura: «En Valencia el Centro está ganando de día en día mayor actividad. Trabajan en él Dámaso Alonso, Rodríguez Castellano, Moñino, Rosenblat, Bonfante, Alarcos, Sánchez Barrado, Martínez Torner y algunos becarios auxiliares. Está instalado en la planta principal de la Casa de la Cultura donde Rodríguez Castellano actúa de Bibliotecario. Se están trayendo de Madrid los libros necesarios para que la Biblioteca sea un buen instrumento de trabajo» ${ }^{95}$.

Años más tarde, Lapesa, que había permanecido en Madrid, se expresaría en estos emocionantes términos

Pero a aquel último reducto de convivencia llegaban continuamente noticias adversas: Bonfante y Rosenblat fueron expulsados de la zona republicana; Castro, Salinas y Sánchez-Albornoz, en exilio y destituidos por el gobierno de Burgos o Salamanca, lo fueron también por el de Barcelona [...]. Movilizado nuevamente en 1938, dejé aquella especie de secretaría en manos del modelo de noble humanidad que fue don Benito Sánchez Alonso; pero seguí frecuentando el Centro cada vez más despoblado. Y confieso que, deambulando por aquellos despachos y pasillos solitarios, lloré más de una vez, convencido de que, cualquiera que fuese la suerte de la contienda, el Centro y su espíritu no sobrevivirían ${ }^{96}$.

\section{CARTAS A MENÉNDEZ PIDAL}

16. Las cartas que editamos a continuación (en Anexo) fueron enviadas por Rosenblat a Menéndez Pidal en el periodo comprendido entre 1949 y 1958. En ellas se puede apreciar la amistad personal y científica que cultivaba con el maestro. Le hacía partícipe de todos los acontecimientos de su vida profesional y personal, le pedía consejos, le hablaba de los amigos o le expresaba sus sentimientos a tenor de algunos acontecimientos importantes en la vida de don Ramón Menéndez Pidal. Pero sobre todo le hablaba de discusión de problemas científicos y le pedía datos por la escasez de materiales con que trabajaba en Venezuela. En estas cartas asistimos al trabajo cotidiano en el taller de Rosenblat, a su procedimiento metodológico; también, en el último documento y en algunas anotaciones al margen, se aprecia cómo atendió Menéndez Pidal a las consultas y peticiones del filólogo ya con nacionalidad venezolana ${ }^{97}$.

95 Archivo de la Residencia de Estudiantes, signatura JAE 280790340/JAE/168/16/45.

96 LAPESA, 1979: 76-77.

97 No se nos oculta el hecho de que sería interesante editar la correspondencia en la otra dirección, para ver el intercambio de ideas entre Menéndez Pidal y Rosenblat. Tal vez pueda hacerse a 
Como se verá, la personalidad del autor se deja captar a veces. Y resulta evidente que estaba unido a Menéndez Pidal en su visión de la lengua, por los estudios filológicos. Las cartas que le escribió muestran con toda claridad la filiación filológica de Ángel Rosenblat, cuya obra estuvo inspirada y presidida por el espíritu del Centro de Estudios Históricos.

\section{BIBLIOGRAFÍA}

Alonso, Amado, Castellano, español, idioma nacional: historia espiritual de tres nombres, Buenos Aires, Losada, 1942.

ALVAR, Manuel, «Angel Rosenblat», Letras, 29 (Caracas, 1973): 67-70.

, y QuILIS, Antonio, Atlas Lingüístico de Hispanoamérica. Cuestionario, estudios introductorios de Manuel Alvar, Madrid, Instituto de Cooperación Iberoamericana, Madrid, 1984.

Manuel, Llorente, Antonio, SAlvador, Gregorio, Textos andaluces en transcripción fonética, edición de Manuel Alvar y Pilar García Mouton, Madrid, Gredos, 1995, 442 págs.

Bernabéu Albert, Salvador y NARANJo Orovio, Consuelo (eds.), «Historia contra la «desmemoria» y el olvido: el americanismo en el Centro de Estudios Históricos y la creación de la revista Tierra Firme (1935-1937)», Tierra Firme, edición facsimil, Madrid, Residencia de Estudiantes-CSIC, 2007, estudio introductorio.

Boyd-Bowman, Peter, Léxico Hispanoamericano (1493-1993), eds. Ray Harris-Northall y John Nitti, CD-Rom, Hispanic Seminary of Medieval Studies, 2003.

CISNEROS, Luis, «Amado Alonso y El lenguaje peruano», XX/ 1-2 (Lima, 1996): 87-100.

COSERIU, Eugenio, Tradición y novedad en la ciencia del lenguaje. Estudios de historia de la lingüística, Madrid, Gredos, 1977.

CuERVo, Rufino José, «El castellano en América», Bulletin Hispanique, III, (Toulouse, 1901): $35-64$

DICCIONARIO de Venezolanismos, dirección y estudio preliminar de María Josefina Tejera, tomo I, A-I, Caracas, Academia Venezolana de la Lengua/ Universidad Central de Venezuela, 1983-.

EsPinosA, Aurelio M., The Spanish language in New Mexico and Southern Colorado, Historical Society of New Mexico, no 16, mayo 1911, Santafé 37 págs. [Revue de Dialectologie Romane, Studies in New Mexican Spanish, part I: Phonology, tomo I, 1909, págs. 157-239, 269-300; Part II: Morphology, tomo II, 1911, págs. 241-256;

partir de la documentación que se conserva en Caracas, habida cuenta de que según María Josefina Tejera el archivo con la correspondencia y los manuscritos de Rosenblat está ordenado y a disposición de los investigadores en el Instituto de Filología. TEJERA, 12-13 [Caracas, 1997]: 177. 
tomo IV, 1912, págs. 251-286; tomo V, 1913, págs. 142-172. Part III: The English Elements, tomo VI, 1914, págs. 241-317. Reseñas: CC. MARDEN, Modern Language Notes, XXVI (Baltimore, 1911): 156-157; A. CASTRO y T. NAVARro TOMÁs, Revista de Filología Española, V (Madrid, 1918): 195-198. G. MillardeT, Romania, XLII (París, 1913): 462-463.

, Estudios sobre el español de Nuevo Méjico, Parte I. Fonética, traducción y reelaboración con notas por Amado Alonso y Angel Rosenblat, con nueve estudios complementarios sobre Problemas de dialectología hispanoamericana por Amado Alonso, Buenos Aires, Universidad de Buenos Aires, 1930 [Biblioteca de Dialectología Hispanoamericana, tomo I].

, Estudios sobre el español de Nuevo Méjico, Parte I. Morfología, traducción, reelaboración y notas de Ángel Rosenblat, Notas de Morfología dialectal por Ángel Rosenblat, Buenos Aires, Universidad de Buenos Aires, 1946 [Biblioteca de Dialectología Hispanoamericana, tomo I].

ESTUDIOS dedicados a Menéndez Pidal, 8 vols., Madrid, Patronato Marcelino Menéndez y Pelayo, 1950-1962.

Frago Gracia, Juan Antonio, Historia del español de América. Textos y contextos, Madrid, Gredos, 1999.

Frago GraCiA, Juan Antonio, «Sobre la criollización del español de América: apuntes documentales y metodológicos», Boletín de Filología, XXXVII, (Santiago de Chile, 1998-1999): 523-539. [Homenaje a Ambrosio Rabanales].

García Mouton, Pilar, ed., El español de América 1992, prólogo de Antonio Quilis, Madrid, CSIC, Anejos de la Revista de Filología Española, 2003.

Gili GAYA, Samuel, «Espinosa, A.M. Estudios sobre el español de Nuevo Méjico. Parte II, Morfología. Traducción, reelaboración y notas de Angel Rosenblat, Buenos Aires, 1946, xvi + 394 págs», Revista de Filología Española, XXX (Madrid, 1946): 176-177.

GONZÁlEZ OlLÉ, Fernando, «La precaria instalación del español en la América virreinal», Anuario de Lingüística Hispánica, XII-XIII (Valladolid, 1996-1997): 327-360 [Homenaje a Germán de Granda].

GRAHAM, Helen, Breve historia de la guerra civil, Madrid, Espasa Calpe, 2006.

Guitarte, Guillermo L., «Una carta de Amado Alonso a Rodolfo Lenz. El proyecto de un corpus de estudios sobre el español peninsular», Lexis, XX/ 1-2, (Lima, 1996): 63-86. [Centenario de Amado Alonso (1896-1996): Temas de filología hispánica, eds. Luis Jaime Cisneros y José Luis Rivarola].

HenríQuez UreñA, Pedro, «Observaciones sobre el español de América», Revista de Filología Española, VIII (Madrid, 1921): 357-390; «Observaciones sobre el español de América. II», Revista de Filología Española, XVII (Madrid, 1930): 277-284; íd., «Observaciones sobre el español de América. III. Comienzos del español en América», Revista de Filología Española, XVIII (Madrid, 1931): 120-148. 
HomenAJE a Ángel Rosenblat, Filología, XXI/ 2, (Buenos Aires, 1986).

IORDAN, Iorgu, y MANOLIU, María, Manual de lingüística románica, revisión, reelaboración parcial y notas por Manuel Alvar, Madrid, Gredos, 1972.

Jauralde Pou, Pablo, «Cervantes y la Escuela de Filología Española», Voz y Letra, XVI/1-2 (Madrid, 2005): 3-14.

LAPESA, Rafael, «Menéndez Pidal, creador de escuela: el Centro de Estudios Históricos», en ;Alça la voz, pregonero!. Homenaje a don Ramón Menéndez Pidal, Madrid, Cátedra Seminario Menéndez Pidal, 1979: 43-79.

SÁNCHEZ, Alberto, «Reseña a Rosenblat, Ángel, La lengua del Quijote, Madrid, Gredos, 1971», Anales cervantinos, 11 (Madrid, 1972): 177

LAPESA, Rafael, «Recuerdo y legado de Amado Alonso», Lexis, XX/ 1-2 (Lima, 1996): 11-29.

LERNER, Isaías en http://asociacioninternacionaldehispanistas.org/angel.html

LOPE BLANCH, Juan M., «Reseña a: Rosenblat, Ángel, Las generaciones argentinas del siglo XIX ante el problema de la lengua», Hispanic Review, 31 (Filadelfia, 1963): 286-288.

, prólogo de Estudios sobre el español de América, Biblioteca Ángel Rosenblat, tomo III, Caracas, Monte Ávila Editores, 1990, 421 págs.

MARTínez MARÍN, Juan, «El español de América en la obra de Amado Alonso», Estudios de Lingüistica de la Universidad de Alicante, 15 (Alicante, 2001): 177-186.

Memoria correspondiente a los cursos 1933 y 1934, Madrid, Junta para Ampliación de Estudios e Investigaciones Científicas, 1935.

MEIER, Harri, Reseña a: «Espinosa-Rosenblat, Estudios sobre el español de Nuevo Méjico», Romanische Forschungen, 63/1-2 (Frankfurt am Main, 1951): 424-427.

MENÉNDEZ PIDAL, Ramón, «Prólogo», Romance Philology, 17/1, (Berkeley, 1963): 5-8.

MorínIGO, Marcos A., «Homenaje a Ángel Rosenblat (1904-1984)», Filología, XXI/2 (Buenos Aires, 1986): 5-9.

NAVARro, TOMAS, «Reseña a Aurelio M. Espinosa, Estudios sobre el espanol de Nuevo Mejico. Parte II: Morfología», Romanic Review, $39 / 4$ (Nueva York, 1948:Dec): 340341.

PÉREZ, Francisco Javier, «El filólogo venezolano Ángel Rosenblat. Su caracterización como lingüista-historiador», Revista de Filología de la Universidad de La Laguna, 21 (Tenerife, 2003): 253-266.

Rosenblat, Ángel, La lengua y la cultura en Hispanoamérica. Tendencias lingüísticas y culturales, conferencia pronunciada en el «Romanisches Seminar» de la Universidad de Berlín el 1 de febrero de 1933, publicada en la colección «Vom Leben und Wirken der Romanen», 1, Spanische Reihe, Heft 3, Jena y Leipzig, 1933, 28 págs.; $2^{\mathrm{a}}$ 
ed..: Anales del Instituto Pedagógico, Caracas, 4, 1949: 265-293; $3^{\mathrm{a}}$ ed.: avant-propos de Marcel Bataillon, Paris-Toulouse, Librairie des Editions Espagnoles, 1951, 29 págs.; 4a ed.: Lima, Universidad de San Marcos, Anejo de Sphinx,13, 1960, 1; $5^{\mathrm{a}}$ ed.: Caracas, Ministerio de Educación, 1962.

, «Reseña a: Toro, Miguel de, L'évolution de la langue espagnole en Argentine, Paris, Librairie Larousse, 1932», Revista de Filología Española, XX (Madrid, 1933): 297-300.

, «Reseña a Matthies, Werner, Die aus den intransitiven Verben der Bewegung und dem Partizip des Perfekts gebildeten Umschreibungen im Spanischen, Jena y Leipizig, Gronau, 1933, 66 págs», Revista de Filología Española, XX (Madrid, 1933): $406-408$.

, «El desarrollo de la población indígena de América», Tierra Firme, I (Madrid, 1935): 115-127; 1/2:117-148; I/3: 109-141. $2^{\mathrm{a}}$ ed. reelaboración completa con un apéndice, La población indígena de América desde 1492 hasta la actualidad, Buenos Aires, Institución Cultural Española, 1945, 296 págs. $31 \mathrm{cms}$. $3^{\mathrm{a}}$ ed. reelaboración y ampliación, el apéndice sobre «El mestizaje y las castas coloniales» aparece convertido en el volumen II de la obra: La población indígena y el mestizaje en América, Buenos Aires, Editorial Nova, 1954.

Reloj de príncipes y Libro de Marco Aurelio, edición, prólogo y notas de A. Rosenblat, Madrid, Signo, 1936, 171 págs. Reseña: E. A., Revista de Filología Española, XXIII (Madrid, 1936): 317 -318.

, «Reseña a: Mézan, S., De Gabirol à Abravanel. Juifs espagnols promoteurs de la Renaissance», Revista de Filología Española, XXIII (Madrid, 1936): 422-423.

, «Reseña a: Rufino José Cuervo, El castellano en América, Bogotá, Editorial Minerva, Biblioteca Aldeana de Colombia, 1935», Tierra Firme, II/2, (Madrid, 1936): 321-325.

,«Reseña a Initiation de la vie en Argentine, par Max Daireaux, et al, París, Armand Colin, 1935», Tierra Firme, II/3-4, (Madrid, 1936): 565-567.

, «Los otomacos y taparitas de los Llanos de Venezuela», Tierra Firme, II/1, (Madrid, 1936) 131-153; II/2, 1936: 259-304; II/3-4: 439-514.

, «Reseña a Iorgu Iordan, An introduction to Romance Linguistics. Its schools and sholars, revised, translated and in parts recast by John Orr, Londres, Methuen and Co. Ltd., 1937, xii-404 págs», Revista de Filología Hispánica, II (Buenos Aires, 1940): 182-183.

, «Las ideas ortográficas de Bello», Estudios gramaticales, Obras Completas de Andrés Bello, tomo V, Caracas, Ministerio de Educación, 1951. , «Amado Alonso», Cultura Universitaria, XXXI (Caracas, 1952): 61-71. , «El género de los compuestos», Nueva Revista de Filología Hispánica, México, VII, 1-2, 1953: 95-112. 
, Buenas y malas palabras en el castellano de Venezuela, con prólogo de Mariano Picón-Salas, Caracas/ Madrid, Ediciones Edime, 1956.

, «Cultismos masculinos con $-A$ antietimológica», Filología, V/1-2, (Buenos Aires, 1959): 35-46.

, «Morfología del género en español. Comportamiento de las terminaciones en -o, -a», Nueva Revista de Filología Hispánica, XVI (México, 1962): 31-80.

, La primera visión de América y otros estudios, Caracas, Ministerio de Educación/ Dirección Técnica, Departamento de Publicaciones, 1965.

, «Nota autobiográfica», María Josefina Tejera, Ángel Rosenblat, Caracas, Universidad Central de Venezuela, Facultad de Humanidades y Educación, Escuela de Biblioteconomía y Archivos, 1967: 11-17. Nuestra lengua en ambos mundos, Estella, Salvat, 1971.

, La lengua de El Quijote, Madrid, Gredos, 1971; 2005.

STEFANO, Luciana de, «Ángel Rosenblat», Boletín de Lingüística, 19 (Caracas, 2003): 86-96.

STEFANO, Luciana de, «Rosenblat, trayectoria de una obra», Revista Nacional de Cultura, LXIV/ 328, (Caracas, 2004. [online]).

TEJERA, María Josefina, Ángel Rosenblat, Caracas, Universidad Central de Venezuela, Facultad de Humanidades y Educación, Escuela de Biblioteconomía y Archivos, 1967.

, «Bibliografía de Angel Rosenblat», Estudios filológicos y lingüísticos. Homenaje a Ángel Rosenblat en sus 70 años, Caracas, Departamento de Cultura y Publicaciones del Inst. Pedagógico de Caracas, 1974: 543-565. [edición dirigida por Luis Quiroga Torrealba, Mario Torrealba Lossi y Pedro Díaz Seijas].

, «Palabras de despedida», Boletín de Lingüística, 12-13 (Caracas, 1997): 175179. [L aniversario de la creación del Instituto «Andrés Bello»].

, «Reseña a Biblioteca Rosenblat, 1987, Caracas, Monte Ávila Editores», Boletín de Lingüística, 12-13 (Caracas, 1997): 183-186.

VAQUERO, María, «La Dialectología hispanoamericana en los últimos veinticinco años», Lengua Española Actual, XXVI/ 2 (Madrid, 2004): 101-123.

Vega, Garcilaso de la «El Inca», Comentarios Reales de los Incas [ed. facsímil de la princeps editada en 1609], estudio de J. L. Rivarola, Madrid, Ediciones de Cultura Hispánica de la Agencia Española de Cooperación Internacional, 2002, 264 págs.

WAGNER, Max Leopold ««El supuesto andalucismo de América» y la teoría climatológica», Revista de Filología Española, XIV (Madrid, 1927): 20-32. 


\begin{abstract}
ANEXO
[DOCUMENTO 1: carta mecanografiada; lugar y fecha: Caracas, 10 de octubre de 1949; dirigida a: Sr. D. Ramón Menéndez Pidal/ Chamartín de la Rosa/ Madrid]

\section{Mi querido Don Ramón:}

Hace quince días le envié a D. Rafael de Balbín Lucas, para el Homenaje a R. Menéndez Pidal, un trabajo sobre «El género de los sustantivos en -e y en consonante». La verdad es que el trabajo alcanzó doble extensión de la que yo había calculado, pero poniendo toda la documentación en tipo menor quizá quepa en los límites fijados. En último caso, he indicado la supresión de la parte final, pero realmente esa supresión me dolería muchísimo.

Ese trabajo es un capítulo de mi tesis doctoral: «Morfología del género en español». Esa tesis, que debió publicarse en el Instituto de Buenos Aires, daba unas 500 páginas. Desde entonces he reunido una inmensidad de materiales nuevos y tendría que rehacerla íntegramente. Daría ahora un libraco inmenso e indigesto. Amado Alonso me aconseja que lo aligere publicando capítulos sueltos. Siguiendo ese consejo, he rehecho uno de ellos — me parece que es el más interesante — para el Homenaje a usted. ¡Ojalá le guste!

¿Cuándo aparecera el Homenaje? La situación del mundo (y de España) no es en sus ochenta años como era en sus sesenta (¡qué hermosos aquellos tres volúmenes del HMP!). Pero espero que la vieja comunidad filológica, que no puede romperse a pesar de todas las catástrofes, dé nuevas pruebas de su existencia. Me gustaría que este nuevo Homenaje fuera una gran obra de concordia.

Mis pichones de filólogos quedaron encantados y emocionados con la carta de usted. También Carmen Helena, que me pide que lo salude a usted calurosamente. Mi instituto creo que ha progresado algo. Tengo un grupo de muchachos entusiastas, que están trabajando bien. Estamos preparando un gran Diccionario de venezolanismos (de la lengua escrita y hablada, desde los cronistas hasta hoy) y estudiando el habla actual. Lo que creo que más les interesa es el estudio de la lengua literaria, especialmente de los autores venezolanos.

Últimamente he publicado algunas cosas, que le he hecho enviar: un estudio de la lengua de Cervantes, una conferencia sobre el pensamiento gramatical de Bello y cosas menores. En Buenos Aires ha salido una edición mía de las Cartas de Lope de Vega, que había preparado antes de venir para acá (sobre el texto de G. de Amezúa, enmendando algunas lecturas y completando los dos pasajes que él mutiló). En Caracas estamos un poco aislados del mundo filológico (y del mundo en general).

Me alegraré muchísimo de tener buenas noticias de usted. Poniéndome a sus órdenes, le saludo con el cariño de siempre
\end{abstract}

Ángel Rosenblat 
[DOCUMENTO 2: carta mecanografiada; lugar y fecha: Caracas, 14 de noviembre de 1950; dirigida a: Sr. D. Ramón Menéndez Pidal/ Chamartín/ Madrid; en margen, autógrafo: s/c Calle nueva (Puente Paraíso a Puente Ayacucho) Quinta Helena. El Paraíso Caracas]

\section{Mi querido Don Ramón:}

Me he alegrado muchísimo de recibir carta de usted, y la alegría la han compartido mis discípulos caraqueños, que siguen con interés toda su obra. He recibido también, con amable dedicatoria, su «Lengua de la época de los Reyes Católicos» y su conferencia sobre el romancero. He leído además últimamente la publicación - tan hermosamente ilustrada por Gonzalo - sobre «Cómo vive el romancero». Estoy asombrado de cómo puede usted remozar día a día sus viejos temas. El año pasado di en la universidad un curso sobre la épica a través de toda la literatura, y he tenido ocasión de manejar casi toda su obra. (Tampoco me falta ocasión para lo mismo en el curso de Historia de la lengua que hago todo los años). Estoy impaciente por su Historia de la épica, que espero que saldrá pronto.

He recibido el tomo I de los Estudios publicados en su Homenaje. Es un volumen denso, de materia rica y variada. La obra en su conjunto va a ser monumental, digna de aquellos tres hermosos volúmenes de los sesenta años, que son hoy obra fundamental de consulta para mil cuestiones de nuestra filología. Me alegro mucho de que mi trabajo sobre vacilaciones de género aparezca en uno de los seis volúmenes. Era un trabajo de treinta páginas, pero al reelaborarlo llegó a sesenta. Me dicen que el tomo II ya ha salido, pero tardan muchísimo en llegar los libros hasta esta tierra.

Un dato curioso: Entre los libros prestados por la Biblioteca Nacional de Caracas ocupan el primer lugar los libros de usted. Me parece un síntoma muy bueno: indica que los profesores de literatura están teniendo una orientación moderna y técnica. La enseñanza hasta ahora ha sido muy deficiente, y creo que lo sigue siendo. Pero me parece que se progresa día a día. La deficiencia fundamental con que chocamos es la falta de libros, sobre todo libros viejos y eruditos. Todo lo que hay es adquisición reciente. En el Instituto de Filología hemos podido conseguir últimamente la colección completa de la Revista de Filología Española, y ha sido una suerte. Me gustaría tener en el Instituto un retrato de usted. ¿Sería posible conseguirlo?

¿Le he dicho a usted que estamos preparando aquí un gran Diccionario de venezolanismos? Tenemos ya más de 30.000 papeletas ordenadas. Hemos empezado por la lengua actual (hablada y escrita) para llegar hasta los primeros cronistas. Tengo ahora un pequeño problema con la palabra hato, que significa 'hacienda de campo, dehesa'. Está documentada desde principios del XVI, y seguramente era uso de los conquistadores. Pero no la encuentro documentada en España. El Diccionario de Serrano dice que en España significaba 'redil, aprisco'. Me gustaría comprobarlo con algún autor o testimonio.

Estoy preparando en este momento un estudio ortográfico, mejor dicho, un panorama histórico de la ortografía española, que va a servir de prólogo a uno de los tomos de las Obras completas de Andrés Bello. El objeto es presentar la reforma ortográfica de Bello a la luz de un momento histórico en que la Academia estaba reformando activamente la ortografía. Se ha aceptado, y yo he tenido parte en ello, publicar las Obras con ortografía 
académica. Para hacer el estudio como quisiera tropiezo con falta de materiales. ¿No hay un estudio sistemático de la ortografía alfonsí? No he podido conseguir ni su edición de la Primera Crónica. Utilizaré, claro está, a la Viñaza, con todas sus erratas. ¿Conoce algún trabajo especial que me pueda servir?

Hemos estado todos muy preocupados por la salud de Amado Alonso. ¿Ha tenido usted noticias últimas? Espero tener muy buenas noticias de usted, y mientras tanto reciba usted un cariñoso abrazo

Angel Rosenblat

[DOCUMENTO 3: carta manuscrita autógrafa; lugar y fecha: Caracas, 25 de agosto de 1951; dirigida a: Sr. D. Ramón Menéndez Pidal/ Chamartín de la Rosa/ Madrid]

\section{Mi querido Don Ramón:}

Acabo de recibir el tomo II de los Estudios dedicados a usted, y me he alegrado muchísimo de que esa hermosa empresa siga viento en popa. Supongo que el tomo III saldrá pronto. Se ha empezado aquí la campaña para que le den a usted el Premio Nobel. Yo me alegraría muchísimo, por usted y por nuestra Filología. Aquí tiene usted muchísimos admiradores.

Le envío a usted la nota sobre hato. Pude agregar la noticia de Pedro Espinosa, que usted me había enviado y que era importantísima. Se la agradezco a usted de todo corazón. La verdad es que trabaja uno aquí en condiciones muy precarias, sin los instrumentos más imprescindibles.

Acabo de terminar una «Historia de la ortografía castellana» que irá como prólogo (más de cien páginas) de uno de los tomos de las Obras completas de Bello que se están publicando aquí. Me interesaba presentar las ideas y la reforma de Bello con una perspectiva amplia. En mitad del trabajo me llegó la noticia de que Alarcos estaba haciendo la historia completa para Dámaso. Así sucede siempre. De todos modos he dejado de lado una serie de problemas, en que había adelantado mucho: historia de la acentuación, de la puntuación, mayúsculas, sílabas, unión y separación de palabras, etc. Cuando salga el libro de Alarcos veré qué hago con lo mío, si lo convierto en reseña o hago otro libro. El trabajo que he hecho me ha llevado tres veces más tiempo que si lo hubiera hecho en Madrid. Pero esos méritos sólo Dios los puede apreciar, porque supongo que toma en cuenta hasta las manotadas en el vacío.

En la primera parte (orígenes hasta Alfonso el Sabio) no he hecho más que resumir sus trabajos. Tengo sin embargo una duda. ¿Cómo se generaliza en España, en los primitivos documentos, la $\underline{z}$, en vez de continuarse por tradición la ce latina. He visto en autores franceses la idea inversa, y explican la ç como una $\underline{z}$ suscrita debajo de la $\underline{c}$, que era lo general? No sé si hay ahí algo que no he entendido bien en los Orígenes.

Veo que ha salido una nueva edición, pero no ha llegado aún a estas tierras, tan alejadas del mundo. Sí he sentido los Cinco reinos. ¡Precioso! Todos sus libros circulan aquí como el pan nuestro de cada día.

En la pequeña historia de la ortografía castellana que ha hecho usted en el tomo España de la Enciclopedia Espasa (¿es de usted, verdad?) leo que Colombia, Ecuador y Costa Rica 
adoptaron oficialmente la ortografía chilena en el siglo pasado. He escrito a esos países pidiendo información más amplia, pero aún no he recibido respuesta. ¿Recuerda usted las fuentes de su información? Seguramente en la Academia habrá algo.

¡Menuda alharaca la que han armado las academias en su congresillo de Méjico! La política se mete en todo, por desgracia. Los mejicanos son capaces de revolucionarlo todo, ipero, por Dios, que no les toquen la $\underline{x}$, que es sagrada!

¡Horror! Veo que le estoy haciendo a usted consultas que pueden sacarlo de sus trabajos. No me haga usted caso. Las noticias de Amado Alonso han vuelto a ser malas. Le han operado de la vesícula (cálculos), y me escriben que está bien. ¡Ojalá sea verdad! ¡Cuántas tribulaciones!

Carmen Helena, gran admiradora de usted, me pide que le envíe un cariñoso saludo, para usted y para los suyos. Helenita está muy bien, y yo, que soy su intérprete, sé que ella se suma a todos nuestros deseos. Muy cordialmente

Angel Rosenblat

[DOCUMENTO 4: carta manuscrita autógrafa; lugar y fecha: Caracas, 25 de enero de 1952; dirigida a: Sr. D. Ramón Menéndez Pidal/ Chamartín de la Rosa/ Madrid]

\section{Mi querido Don Ramón:}

Ya ve usted que le quieren traer a Caracas. Yo me alegraría muchísimo, y todos aquí. A las personas que me han preguntado si usted vendría, les he contestado que me parecía difícil, por sus muchos trabajos. Pero ojalá sí. Usted decide.

¿Cómo se ha retrasado tanto el tomo III del Homenaje? Creo que iba a ir en él mi humilde y extensa aportación. Ya me gustaría ver ese tomo, y los demás.

Lo último que he leído de usted es la nota sobre Murcia y Mortera, muy hermosa, y el formidable artículo del Boletín de la Academia. Siempre llegan aquí las cosas, aunque un poco retrasadas.

He terminado mi breve historia de la ortografía castellana. Irá como prólogo (unas 130 páginas) del tomo $\mathrm{V}$ de las Obras completas de Bello. He dejado de lado la historia de la acentuación, puntuación, etc. que algún día pueden darme un volumen. Pero espero que salga antes el tomo de Alarcos, anunciado por Gredos. En tanto estoy preparando una nueva edición de mi Población indígena, que tengo ya en pruebas. Aquí, por mil dificultades, se trabaja con mucha lentitud.

Amado Alonso ha estado de nuevo enfermo, con pulmonía. Es increíble la cantidad de males que se han lanzado contra él desde que llegó a los Estados Unidos. En Buenos Aires era para nosotros modelo de salud, del cuerpo y del alma. ¡Ojalá sobrepase esta temporada horrible!

Me alegraré de tener buenas noticias de usted. Espero que estará muy bien y que progresarán todos sus trabajos. Saludos cordiales de Carmen Helena. Un gran abrazo

Angel Rosenblat 
[DOCUMENTO 5: carta manuscrita autógrafa; lugar y fecha: Caracas, 18 de noviembre de 1952; dirigida a: Sr. D. Ramón Menéndez Pidal/ Chamartín de la Rosa/ Madrid; en margen, escrito por Menéndez Pidal: «en la Rioja se uso macán, -ano 'necio, bruto, bárbaro'/ El macandón de Lucas Fernández/ Escudero decidor y burlón]

\section{Mi querido Don Ramón:}

Hace mucho que quería escribirle. Por Sanabria, por Grases, por Magariños, he tenido noticias de usted. Las he tenido además por sus constantes publicaciones. Todos tenemos que dar gracias a Dios de que nos lo conserve con esa maravillosa salud espiritual y esa actividad prodigiosa. Que así sea por muchísimos años.

La muerte de Amado Alonso ha sido para mí un golpe muy duro. Siempre lo he considerado a él mi padre, y a usted mi abuelo. He leído las cariñosas páginas que le dedicó usted en Ínsula. Le he enviado a usted una nota que publiqué aquí en Cultura Universitaria; espero que la habrá recibido.

Ha salido hermoso el tomo III de su Homenaje. Me alegro de que la obra progrese. ¿Serán cinco volúmenes? Una buena recopilación de trabajos importantes, que hace juego con aquellos formidables tres tomos de los cincuenta años.

Aquí sigo muy lentamente los trabajos. Grases le ha entregado el tomo de Bello con mi prólogo ortográfico. Es increíble el trabajo que aquí da cualquier cosa. Su Primera Crónica General la encontré, después de muchas andanzas, en una biblioteca particular; el Cancionero de Baena, después de buscarlo mucho tiempo, lo encontré en la Academia, revisando libros. ¿Qué se puede hacer en estas circunstancias? En el Instituto estaba formando una biblioteca, con muchas dificultades. Pero hace un año, más de un año, que la universidad está cerrada. La política lo perturba todo en nuestros pobres países.

Con todo, algo hay que hacer, para que los abuelos no reniegen del todo de sus nietos. Nuestra revista de Méjico va a dedicar un número doble de homenaje a Amado. Tengo un trabajo sobre dos argentinismos: macana y che. El che no me ofrece problemas: es el ce antiguo y clásico (del $\underline{s t}$ ! latino) conservado en Valencia, Andalucía, Argentina, etc. Tengo mucha documentación, reunida desde hace mucho. Más inquieto estoy por macana 'despropósito, camelo'. Mi idea es que nada tiene que ver con macana, arma indígena (que sí ha dado macanudo). Tengo macana en Andalucía y Aragón (Alcalá Venceslada y Dicc. Acad.), y sobre todo macanar, con el significado al parecer de 'engañar' en Sarmiento de Gamboa, año 1583. ¿Cómo se explica este macanar? ¿No tendrá usted en sus materiales algo que lo aclare? ¿Puede ser mala lectura de un manuscrito. Ese macanar me lleva a macandón, que encuentro en Lucas Fernández (la Academia lo da como anticuado), y hay en Galicia macandad (en Cuba y Colombia macandá), del argot o de Murcia, indudables derivados de maca, que significó 'engaño', y de macar 'engañar'. Esa es mi idea: Una palabra española de argot que de pronto tiene en Buenos Aires una vida esplendorosa de «nouveau riche». Pero le veo dificultades a mi explicación: el salto de maca (o macar) a macana, a pesar de andana, botana, altana, albergana, cebollana, caobana, solana, gordana, perdigana, etc.; ese único testimonio de Sarmiento de Gamboa me parece insuficiente. Siempre me queda la duda de que el sentido argentino haya nacido de una anécdota, como se ha querido explicar. ¿Qué opina usted? ¿Debo abandonar esa pista? Me rindo si no me manda usted recursos: alguna macana o algún macanar perdido en 
los textos, como el de Sarmiento de Gamboa. Si la explicación no es del todo convincente, en la Argentina no me perdonarían que les quitara el patrimonio de la macana. Quizá alguno de sus secretarios me podrá reunir un par de datos. Aquí ya he agotado todas mis posibilidades.

Pronto va a salir la segunda edición (o tercera) de mi Población indígena; la he rehecho o ampliado en gran parte. Los libros españoles llegan aquí con cierto retraso. Estoy esperando que aparezcan en librería algunos de los que he visto anunciados en los boletines bibliográficos.

Carmen Helena le envía saludos muy afectuosos. Siempre se alegra cuando llegan noticias de usted. ¿No le he participado a usted el nacimiento de Miguel Angel? Helenita y él están muy bien, a Dios gracias. Espero que resulten buenos filólogos, admiradores suyos.

Esperando sus noticias, le saluda con el cariño de siempre

Angel Rosenblat

[DOCUMENTO 6: carta manuscrita autógrafa; lugar y fecha: Caracas, 22 de diciembre de 1954; dirigida a: Sr. D. Ramón Menéndez Pidal/ Chamartín de la Rosa/ Madrid]

\section{Mi querido Don Ramón:}

Cuando me disponía a enviarle una alegre tarjeta de Navidad, me llega — con inexplicable retraso - la dolorosa noticia. Carmen Helena y yo lo sentimos en el alma. Después de una vida entera tan llena de las mismas alegrías y de los mismos dolores, esa separación tiene que ser para usted un desgarramiento. Ni siquiera sabíamos que ella estuviera enferma. Acepte usted, querido Don Ramón, nuestra más profunda condolencia. Y trasmítala usted a Jimena y Gonzalo, cuyos trabajos sigo siempre con gran entusiasmo, y a Diego, que es la gran esperanza de nuestra Filología.

Siempre llegan aquí sus grandes y hermosos trabajos, que tienen gran acogida. Los dos tomos del Romancero, estupendos. Muchas gracias por su generoso comentario a la edición de las Obras de Bello. Que este año nuevo nos dé usted una nueva cosecha de trabajos magníficos, que además de lo que valen son una afirmación de soberbia vitalidad consagrada al saber.

Diversas personas que han pasado por Madrid me han traído noticias personales de usted. Que Dios nos lo conserve por muchos años, para bien de todos.

A fines de enero pienso ir a la Universidad de Harvard. Daré clases en el Semestre de primavera. Me habían invitado como profesor de tiempo completo, pero contesté que no podía abandonar mis trabajos en Venezuela.¿Verdad que he hecho bien? Sí me interesa ir por unos meses, para conocer la vida norteamericana y las nuevas corrientes lingüísticas. Llevo ocho años sin salir de Venezuela y creo que me conviene ventilarme un poco. Allá me tendrá usted siempre a sus órdenes.

Una noticia. Según es costumbre en esta tierra, pongo a su orden una señorita, María Luisa Rosenblat, que ya cuenta la friolera de tres semanas. Tiene usted, pues, una admiradora más en esta tierra. 
Esperando siempre tener mejores noticias de usted, le envía un gran abrazo

$$
\text { Angel Rosenblat }
$$

Aunque ya Angel lo ha hecho en mi nombre, quiero decirle yo también cuánto siento la muerte de su señora, y enviarle un saludo muy afectuoso

Carmen Helena

[DOCUMENTO 7: carta manuscrita autógrafa; lugar y fecha: Caracas, 27 de junio de 1956; dirigida a: Sr. D. Ramón Menéndez Pidal/ Chamartín de la Rosa/ Madrid]

\section{Mi querido Don Ramón:}

Hace una eternidad que quería escribirle, y que tenía que escribirle. Hoy aprovecho la ocasión de enviarle fotos de Jimena para hacerlo. Siempre he tenido noticias de usted, por Jimena, por Lapesa, por los amigos venezolanos que han ido al Congreso de Academias. Me he alegrado por el Premio March, y todavía confío en que le darán a usted el Premio Nobel.

Tengo que darle a usted un sablazo tremendo. Mi Universidad ha decidido por fin publicar una Revista de Filología «Andrés Bello». Es la única manera de que mi Instituto no quede aislado en este valle de Caracas. Vamos a publicar una revista semestral (dos números por año, de 240 páginas cada uno). Me interesa que la revista prolongue la tradición del Centro de Estudios Históricos de Madrid y del Instituto de Filología de Buenos Aires. Y por eso me gustaría iniciar el primer número con un artículo de usted. Yo sé que no puedo pedirle un trabajo especial que lo desvíe a usted de sus ocupaciones. Pero quizá nos pueda enviar un capítulo de alguno de los trabajos que tiene en preparación. Algo que no lo saque a usted de sus tareas.

Usted comprende perfectamente la importancia que su colaboración tiene para nuestra Revista y para mí, y sé que pondrá toda su buena voluntad. ¿Puedo contar con su colaboración?

Esperando su respuesta, lo saluda muy cordialmente

Angel Rosenblat

[DOCUMENTO 8: carta manuscrita autógrafa; lugar y fecha: Caracas, 10 de agosto de 1956; dirigida a: Sr. D. Ramón Menéndez Pidal/ Madrid]

\section{Mi querido Don Ramón:}

Estoy encantado de que quiera usted enviarnos algo para la revista de mi Instituto. Se llamará «Revista de Filología «Andrés Bello». Me parece magnífico poner al día sus 
ideas sobre el Entremés de los romances. Si no le parece a usted mal, le ofrezco mi colaboración. Creo que hay que dar el texto del entremés, en edición cuidada. Aquí no tenemos la edición de Adolfo de Castro, y creo que es muy difícil conseguirla. Creo que con ese trabajo de usted (estoy impaciente por ver en qué puede consistir mi colaboración) me parece que la revista se inciaría estupendamente.

Hemos tenido noticias indirectas sobre la operación de Jimena. Esperamos que ya estará enteramente restablecida. Tengo entendido que había un biznieto en perspectiva. ¿Qué noticias tiene usted?

Aquí celebraremos pronto el homenaje a Menéndez Pelayo. Me han pedido una conferencia en la universidad y he dado el siguiente tema: «Milá y Fontanals- Menéndez Pelayo - Menéndez Pidal» ¿Qué me sugiere usted sobre ese tema?

Estoy trabajando bastante. Dentro de unos meses saldrá un libro con un título un poco frívolo que espero que no le desagrade a usted: «Buenas y malas palabras en el castellano de Venezuela». Tengo en preparación varias cosas. Desde Buenos Aires me llamaron para que fuera a dirigir el Instituto de Filología, pero he contraído compromisos con Venezuela y tengo que quedarme aquí. Para mí hubiera sido muy hermoso hacerme cargo del Instituto de Amado, en el que me formé, pero creo que debo ser consecuente con esta tierra, que me ha acogido muy generosamente.

Espero sus noticias. ¿Cómo siguen sus trabajos? He recibido el tomo VI del Homenaje.¡Magnífica obra ese conjunto de volúmenes!. Carmen Helena le saluda muy cordialmente. Un gran abrazo

Angel Rosenblat

[DOCUMENTO 9: postal con foto; lugar y fecha: Caracas, 24 de diciembre de 1956]

\section{Mi querido Don Ramón:}

Un saludo de Pascuas y mis mejores deseos para el año nuevo. Que lleve usted adelante sus grandes trabajos y vea felices a todos los suyos.

Espero siempre la colaboración de usted para iniciar mi revista. Le he hecho enviar El nombre de Venezuela, que espero habrá llegado ya a sus manos. Aviso a Madrid para que le remitan (acaban de terminarlo allá) mis Buenas y malas palabras en el castellano de Venezuela. Son mis trabajos últimos. Más contento estoy de Helena, Miguel Angel y María Luisa, que le envío en facsímil.

Saludos a Jimena. Un gran abrazo.

Angel Rosenblat 
[DOCUMENTO 10: carta mecanografiada; lugar y fecha: Caracas, 20 de junio de 1958; dirigida a: Sr. D. Ramón Menéndez Pidal/ Chamartín de la Rosa/ Madrid; interlineados, escritos por Menéndez Pidal: «Cotarelo Colecc. D Entremeses I, p 157 (NBAE) 1911; «Pedí a Magallón 17 set. 58»].

\section{Mi querido Don Ramón:}

Creo que se perdió alguna carta mía (nuestro correo ha sido catastrófico en el último tiempo), y lo siento. Nuestra Revista del Instituto de Filología «Andrés Bello» está ya en prensa y me gustaría muchísimo alguna cosa de usted para iniciarla y colocarla en la estirpe del Centro de Estudios Históricos.

Me interesa muchísimo la copia del Entremés de los romances, que le ruego nos haga copiar o fotocopiar (el que lo haga me puede enviar también la factura de gastos). Me parece importante publicar de nuevo el Entremés, que creo que no es hoy accesible para nadie. ¿No es verdad? Yo no sé si se puede conseguir además el manuscrito, para hacer una edición más escrupulosa.

Me decía usted en una de sus cartas que revisaría y renovaría su estudio sobre la génesis del Quijote para publicarlo con el Entremés en nuestra revista. Me parece magnífico. De todos modos, si usted no pudiera retomar ahora ese tema, yo no sé si es mucho pedirle que nos mande algún capítulo de alguna de las obras que tiene en preparación. No quisiera causarle ningún trastorno en sus planes de trabajo ni crearle problemas.

En resumen, deseo de usted dos cosas: el Entremés de los romances y un artículo (bien un estudio revisado del Entremés o cualquier otra cosa). Mi revista necesita amparase en usted y por eso estoy muy pedigüeño. ¿No me lo toma usted a mal?

Le escribo hoy mismo a Jimena pidiéndole que me apoye en estas cosas. ¡Pobre! ¿Se repone del tremendo golpe recibido? Yo ni sé hablarle de eso. Aquí hicimos mucha amistad. Catalán tenía una vitalidad asombrosa, además de sus otras virtudes. La noticia nos consternó a todos y todavía parece increíble.

Espero que usted se habrá restablecido enteramente de la operación a la vista y que seguirá trabajando como siempre. Mi revista queda detenida esperando su colaboración. Del extranjero sólo tengo un artículo de Bataillon sobre el Padre Las Casas. Lo demás es nuestro: un capítulo mío sobre el género; un estudio de los galicismos de Bolívar; otro sobre la lengua de Miranda; otro sobre los hispanismos de Trinidad; etc. Falta lo suyo y la revista sale en seguida.

Esperando sus noticias, lo saluda muy cordialmente

A. Rosenblat 
[DOCUMENTO 11. Consta de 3 partes:

a) carta borrador mecanografiada con notas manuscritas de Menéndez Pidal; dirigida a: Dr. D. Angel Rosenblat; sin fecha

Mi querido Rosenblat:

La cuestión de la publicación del Entremés de los Romances se dejó de tratar hace tiempo porque no recibí contestación a una carta mía. Ahora al reanudar el antiguo propósito, Jimena no sabe si podrá hacer algo; ahora por lo menos atraviesa unos momentos muy difíciles de estudio, con oposición que no sabe cuando cesará. Aparte de esto, quiero decirle que, aunque el Entremés está publicado por Adolfo de Castro y después por Cotarelo en su Colección de Entremeses, se debe hacer una publicación mejor, comparando las diversas ediciones antiguas que ofrecen variantes y quizás si la imprenta puede componer notas en letra pequeña enfrente de los versos, sería muy útil y convincente el citar los romances en que el entremés se inspira.

Vea Ud. si todo esto no ocuparía demasiado en la revista. El artículo mío ocupa 60 páginas pequeñas de edición Austral (tendría que añadirse bastante en algunos pasajes) y el entremés ocuparía unas 10 páginas más.

Recuerdos a Carmen Helena y que los peques se encuentren bien de salud, siempre suyo afectuoso

b) carta manuscrita autógrafa; lugar y fecha: 23 de junio de 1958; dirigida a: Sra. Jimena de Catalán/ Chamartín de la Rosa/ Madrid]

Querida amiga:

Hace unos días le he escrito a usted y a Don Ramón. Hoy vuelvo a insistir. El proyecto de publicar la revista tiene ya casi dos años, pero el último tiempo había sido para nosotros muy difícil, y en varias ocasiones creí que tendría que emigrar. Por eso fui dejando pasar el tiempo, sin insistir demasiado. Ahora todo está arreglado y ya he mandado el material a la imprenta. La revista se imprimirá aquí. Por eso ahora puedo insistir con más responsabilidad.

Se me ocurre una idea. ¿Por qué no toma usted a su cargo la reedición del Entremés en nuestra revista? Hay que dejar el texto fiel (el del manuscrito, si se encuentra; o el de la edición de 1611, que creo que es la primera) y poner las notas que sean necesarias. Desde luego una nota preliminar sobre el origen del texto y el criterio de la edición. Ya ve usted que le estoy dando trabajo. A mí me parece útil reeditar el Entremés. Yo, por ejemplo, no lo he podido conseguir nunca y he tenido que dar clases sobre él y las ideas de Don Ramón sobre la génesis del Quijote.

El artículo de Don Ramón puede ser sobre el Entremés, poniendo al día la cuestión, o sobre cualquier otra cosa. Mi Instituto es una prolongación del Instituto de Buenos Aires que dirigía Amado Alonso y del Centro de Estudios Históricos. Me interesa que el artículo de Don Ramón, o la colaboración de Don Ramón, cualquiera que sea, represente el signo de esa filiación. Yo soy filológicamente nieto de Don Ramón, y me amparo en mi abuelo.

Revista de Indias, 2007, vol. LXVII, n. ${ }^{\circ} 239,185-220$, ISSN: 0034-8341 
Perdóneme tanta machaconería, que creo que no es habitual en mí. Le ruego que haga lo que pueda, pero no quiero tampoco crearle a usted problemas complejos. De todos modos, por favor, escríbame en seguida.

Muy cordialmente

Angel Rosenblat

c) ficha de trabajo manuscrita de Menéndez Pidal

Entremés de los Romances [en lápiz: Cotarelo Entremeses I, 157 lo da como de Cervantes]

En Parte Tercera de las Comedias de Lope deVega y otros autores Valencia 1611 (?)Barcelona 1612 [Texto de Cotarelo] [Bibl. Nacional R. 14096]-Madrid 1613 [Bibl. Nac. R. 13.854 y Ti 93 3 ] - Sevilla 1613 (?) - Barcelona 1614 [Bibliot. Nac. Ti- 92]

Ver estas variantes si están en las diversas ediciones de esta Parte Tercera (Adolfo de Castro p 143)

\section{Entremés de los Romances (Romanos)}

\section{Personas (Figuras)}

Sale Mari Crespa, Teresa, (Marica), Perico y Pero Tanto (Viejo, vestidos de labradores) (Despues en el cuarto interlocutor:)

Tanto: Tanto por tanto (cuanto) yo os digo...

[Artículo mío 60 pags. pequeñas (pero lo aumentaría algo). El entremes 30 pags de A, castro 8 columnas de ed. Cotarelo. Lo $1^{\circ}$ que debe hacerse es copiar la edic. Cotarelo (mejor que la de Castro)]

This article shows that the Spanish Philological School bore great influence on the work of Angel Rosenblat since his scholarly training days. He took training with Amado Alonso in Buenos Aires and that raised his interest in the American version of the Spanish tongue. The documents in the JAE's archives show that while in Madrid (1933-1937) he undertook American Linguistics under the direction of Américo Castro, and took part in the publication of the "Tierra Firme» review during the war. The edition of the letters sent by Rosenblat to Menéndez Pidal - preserved in the «Fundación Menéndez Pidal»- confirms the philological relations kept with the Director of the «Centro de Estudios Históricos» and the school he promoted.

KEY WORDS: Ideas in the History of Linguistics, the Spanish tongue in America, Dialectology, Spanish Philological School. 